Portland State University

PDXScholar

$10-10-2000$

\title{
Lava and Ice Interaction at Stratovolcanoes: Use of Characteristic Features to Determine Past Glacial Extents and Future Volcanic Hazards
}

\author{
David T. Lescinsky \\ Arizona State University \\ Jonathan H. Fink \\ Portland State University, jon.fink@pdx.edu
}

Follow this and additional works at: https://pdxscholar.library.pdx.edu/geology_fac

Part of the Geology Commons, and the Volcanology Commons

Let us know how access to this document benefits you.

\section{Citation Details}

Lescinsky, D. T., \& Fink, J. H. (2000). Lava and ice interaction at stratovolcanoes: use of characteristic features to determine past glacial extents and future volcanic hazards. Journal of Geophysical Research: Solid Earth (1978-2012), 105(B10), 23711-23726.

This Article is brought to you for free and open access. It has been accepted for inclusion in Geology Faculty Publications and Presentations by an authorized administrator of PDXScholar. Please contact us if we can make this document more accessible: pdxscholar@pdx.edu. 


\title{
Lava and ice interaction at stratovolcanoes: Use of characteristic features to determine past glacial extents and future volcanic hazards
}

\author{
David T. Lescinsky ${ }^{1}$ and Jonathan H. Fink \\ Department of Geology, Arizona State University, Tempe
}

\begin{abstract}
Structures resulting from lava and ice interaction are common at glaciated stratovolcanoes. During summit eruptions at stratovolcanoes, meltwater is produced and travels freely down steep slopes and thin permeable valley glaciers, eroding the ice and enlarging preexisting glacial drainages. As a result, eruptions in this environment have produced few catastrophic floods. Lava flowing into the open channels and voids in the glaciers becomes confined and grows thicker, filling the available space and producing steepsided bodies with smooth, bulbous contact surfaces. Quenching of lava against ice or by water forms small-scale features such as tensional fractures and glass. As the amount of meltwater in contact with the lava increases, the type and abundance of smaller-scale features become similar to those produced during subglacial eruptions into meltwater lakes. Identification of large- and small-scale lava-ice contact features in the field can be used to reconstruct paleoglacial extent and, combined with geochronology of lavas, to determine past paleoclimate. An understanding of lava-ice interaction allows us to better assess the hazards posed by future eruptions at glaciated volcanoes.
\end{abstract}

\section{Introduction}

Sudden melting of glaciers during volcanic eruptions can produce large debris flows and floods that place neighboring populations at risk. Mount Rainier, Washington is a glaciated stratovolcano that is close to the greater Tacoma-Seattle area $(2,600,000$ residents) and has a high probability of a future eruption [National Research Council, 1994]. Due to the hazards it poses, this volcano was designated a "Decade Volcano" by International Association of Volcanology and Chemistry of the Earth's Interior (IAVCEI) during the 1990s - the United Nations' International Decade for Natural Hazard Reduction [National Research Council, 1994]. Mount Rainier has produced lava flows and small explosive events [Sisson, 1995; Sisson and Lanphere, 1997]. Thus it is likely that lava will erupt onto one of the summit's many glaciers in the future.

Surficial lava flows at glaciated volcanoes, unlike other styles of eruption, rarely initiate debris flows or floods because the rate of meltwater production is low and a mechanism for meltwater ponding is often lacking [Major and Newhall, 1989]. At stratovolcanoes, meltwater can drain through relatively thin alpine glaciers (up to $100-150 \mathrm{~m}$ thick) because the ice is permeable [Smellie, 2000]. In contrast, large volumes of water may be trapped by thick ice caps and ice sheets $(>150 \mathrm{~m}$ thick) that have an impermeable basal layer. As a result, lava eruptions under thick layers of ice often produce outburst floods (jökulhlaups).

\footnotetext{
${ }^{1}$ Now at Department of Earth Sciences, University of Western Ontario, London, Canada

Copyright 2000 by the American Geophysical Union.

Paper number $2000 \mathrm{JB} 900214$.

0148-0227/00/2000JB900214\$09.00
}

In this study we examine lava-ice interaction as it relates to stratovolcanoes like Mount Rainier that have alpine glaciers (ice thicknesses $\leq 150 \mathrm{~m}$ ). First, we synthesize observations of historical eruptions to identify the dominant processes and hazards of lava-ice interaction on stratovolcanoes. We then present field studies of older lava flows, characterizing fracture and landform morphologies produced during lava-ice interaction. These features are then used, along with insight gained from eruption observations, to reconstruct two examples of eruptions with lava-ice interaction and to predict the probable course and hazards of a future lava flow eruption at Mount Rainier.

\section{Eruption Observations}

Much of our knowledge of lava-ice interaction comes from observations of historical eruptions and thermal events at glaciated volcanoes. Below we synthesize observations from 18 eruptions to highlight the important processes and recurring phenomena during lava-ice interaction (detailed summaries can be found in Appendices A and B of Lescinsky [1999]). These events occurred primarily at stratovolcanoes that were dominantly mafic.

Most lava flows onto glaciated volcanoes follow a brief period of increased heat output and/or explosive activity. Conductive heat flow and fumarolic activity may cause gradual melting and glacial subsidence over periods of weeks to years (1960s-1970s Mount Wrangell, Alaska, and 1975 Mount Baker, Washington [Easterbrook, 1975; Benson and Motyka, 1978]). With the start of explosive activity, hot pyroclastic debris and spatter may quickly melt snow and ice (both referred to as "ice" below) [e.g., Walder, 1999] or shatter ice and increase permeability. Floods have been produced during this early phase of eruption (1971 Villarrica, Chile, and 1991 Mount Hudson, Chile [González-Ferran, 


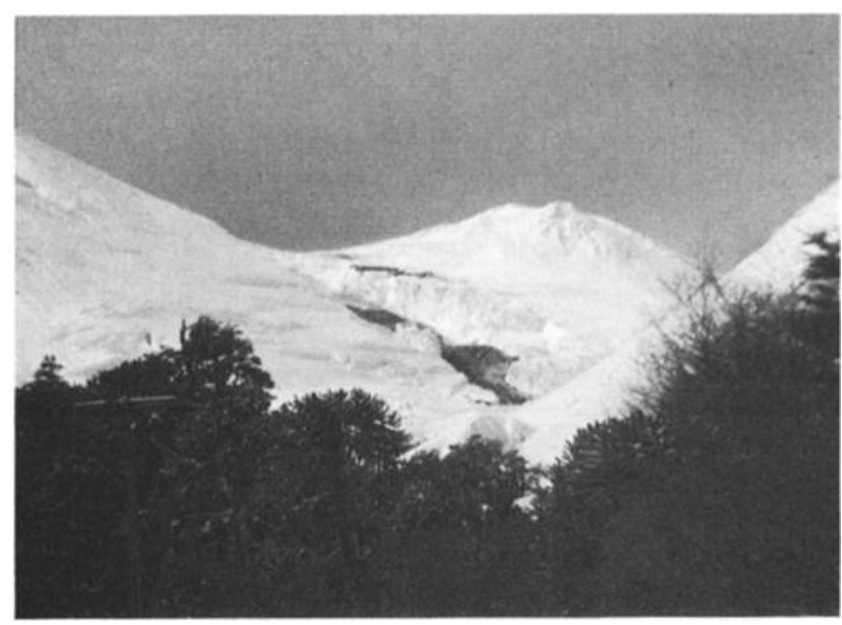

Figure 1. Lava flow visible in a $\sim 50$-m-deep trench melted through summit glacier on Llaima volcano, Chile, during its May 1994 eruption. Main summit of volcano is outside of photo to the left.

1973; Naranjo et al., 1993]). Pyroclastic flows that travel over glaciers may abrade and melt ice and/or trigger avalanches, resulting in large debris flows [e.g., Waitt, 1989; Pierson et al., 1990; Trabant et al., 1994; Meyer and Trabant, 1995].

As ice melts, water not converted to steam travels freely down slope through the existing drainage system. Flowing water erodes ice mechanically by scouring and thermally by friction. Frictional erosion is accentuated on steep slopes where flow velocities are high and may account for a large portion of channel erosion into glaciers (50 to $75 \%$ of the total erosion for water near $0^{\circ} \mathrm{C}$ [Marston, 1983]). Rates of erosion are greatly increased for flows of warm meltwater associated with volcanic activity. Vinogradov and Murav'ev [1988] observed glacial incision rates of $275-550 \times 10^{-6} \mathrm{~m} / \mathrm{s}$ $(1-2 \mathrm{~m} / \mathrm{h})$ by the $50^{\circ} \mathrm{C}$ meltwater runoff during the 1983 Kliuchevskoi eruption. In sum, the flow of warm meltwater on steep stratovolcanoes may rapidly enlarge glacial tunnels and/or cut trenches through a glacier to bedrock.

Lava flows follow the newly modified glacial topography and are frequently constrained by ice, either within trenches (1983-1984 Veniaminof, Alaska [Yount et al., 1985; Reeder and Doukas, 1994]) or subglacial tunnels (1991 Hudson and 1994 Llaima eruptions [Naranjo et al., 1993; Moreno and Fuentealba, 1994]). Undercutting and collapse of the confining ice walls widen trenches, open tunnels upward, and may temporarily dam meltwater (1983 Kliuchevskoi; 1991 Westdahl, Alaska; 1991 Hudson and 1994 Llaima, Chile; Figure 1 [Vinogradov and Murav'ev, 1988; Smithsonian Institution, 1991; Naranjo et al., 1993; Moreno and Fuentealba, 1994; Reeder and Doukas, 1994]). This process may result in sudden meltwater production and accompanying phreatic explosions (1983 Kliuchevskoi, Kamchatka [Vinogradov and Murav'ev, 1988; Vinogradov et al., 1990]). Intense steaming occurs when molten lava comes into contact with ice and substantial runoff is produced, particularly when effusion rates are high (1983 Kliuchevskoi and 1984-1985 Villarrica [Khrenov et al., 1988; McClelland et al., 1989]).

Substantial accumulations of meltwater have occurred within the topographic confines of large craters or calderas associated with thick ice (1991 Hudson and 1983-1984 and 1993-1994 Veniaminof [Yount et al., 1985; McClelland et al., 1989; Naranjo et al., 1993; Smithsonian Institution, 1993, 1994b]). Lavas erupted into this ponded meltwater likely behave as submarine lavas [e.g., Batiza and White, 2000].

When lava is erupted periglacially (in proximity to, but not in contact with, ice) and intersects a glacier, it will either flow onto the glacial surface $(1983,1993$, and 1994 Kliuchevskoi [Khrenov et al., 1988; Vinogradov and Murav'ev, 1988; Smithsonian Institution, 1994a; Belousov, 1996; Zharinov et al., 1996] or be deflected and flow along the glacier margins (1945 Okmok, Alaska [Byers et al., 1947]). Lava traveling over ice causes limited and gradual melting that results in localized subsidence of the flow (1983 Kliuchevskoi [Vinogradov and Murav'ev, 1988]). Such lava flows are prone to instability and collapse, particularly on steep slopes and during periods of increased effusion rate and basal melting (1984-1985 Villarrica and 1994 Kliuchevskoi [ McClelland et al., 1989; Smithsonian Institution, 1994a; Belousov, 1996]). Lava flow collapses can produce volcanic "mixed" avalanches of broken rock and ice, which scour the glacier and can form floods and/or debris flows [Pierson and Janda, 1994].

\section{Lava Flow Structure and Morphology}

Lava flow features formed during historical eruptions of glaciated volcanoes are difficult to study due to their rapid burial by ice. Therefore studies of lava flow structure and morphology were conducted in the North American Cascades Range and at Mount Redoubt, Alaska, where glacial retreat has exposed lava flows that have interacted with ice. Mathews [1951] first proposed that glassy lava margins with subhorizontal polygonal joints or "columns" indicate lava quenching against glacial ice. We have used these basic criteria and knowledge of previous glacial distributions to identify a wide variety of lava structures that can be attributed to lava-ice interaction.

\subsection{Glassy Margins and Fracture Types}

Lava flows that have cooled next to ice typically have a glassy outer shell around a crystalline flow interior (Figure 2) [Lescinsky and Sisson, 1998]. Fracture morphologies found within the glassy outer zone are classified in this paper using the following terms: polygonal, sheet-like, pseudopillow, hackly, and shard-forming (Table 1 and Figures 3 and 4). The fracture morphology groups are somewhat gradational and increase in complexity. As the spacing between fractures becomes smaller, the fractures become less planar and the propagation directions become more variable. These smallscale fracture features, together with larger-scale landform morphology, may be used to identify lava-ice interaction; thus we describe each in detail below.

Polygonal fractures (columnar joints) intersect to form polygons (Figure 3a). They occur at the flow margins, surface, and base of lavas that have interacted with ice (Figures 2, 4a, 4b, and 5b). Along the flow margins and surface, the fractures form narrow columns $(4-8 \mathrm{~cm}$ diameter for rhyolitic-rhyodacite lavas, $5-10 \mathrm{~cm}$ diameter for andesiticdacitic lavas, and up to $20 \mathrm{~cm}$ diameter for basaltic lavas). Fracture orientations are perpendicular to the cooling surface. In some cases, column diameters increase into the flow as 


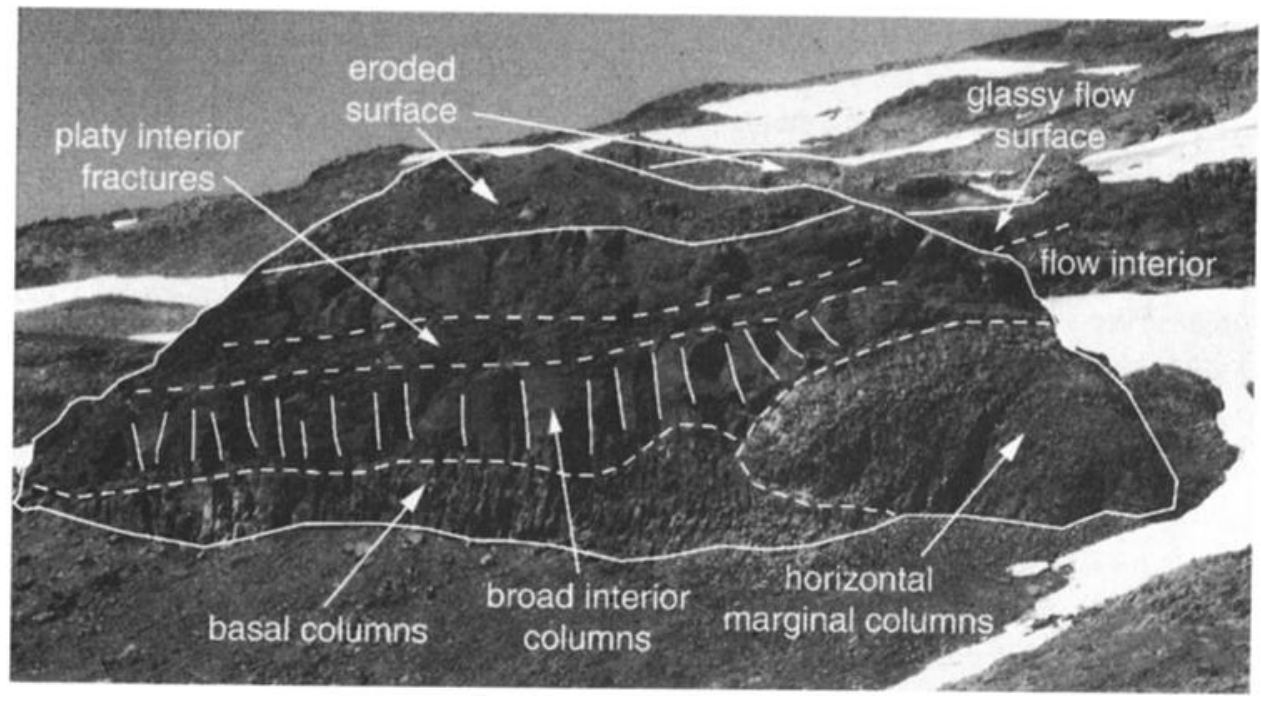

Figure 2. Cross-sectional view of Mazama Ridge flow below the old Paradise ice caves, Mount Rainier, Washington. Polygonal joints (columns) are visible in the glassy flow margin at right and along the flow base. In the crystalline flow interior, platy fractures are present in a zone of broad, poorlydefined columns and in a zone of more massive lava above this. The lava flow surface has been glacially eroded with the exception of a portion of the right side of the flow where a glassy flow surface is preserved. The flow is $\sim 200 \mathrm{~m}$ across and $35 \mathrm{~m}$ high in this photo.

much as 3 times over distances of $<50 \mathrm{~cm}$ by a process of fracture termination (Figure $4 \mathrm{~b}$ ). Vertical columns at the flow base are commonly broader (30-50 cm diameters for andesite to rhyolite and 40-60 cm diameters for basalt). At the intersection of marginal and basal zones, fracture orientations change over a short distance $(-50 \mathrm{~cm})$. Polygonal fracture patterns can be quite complicated, including a variety of fanlike and curving arrangements in the resultant columns. Bands found on the fracture surfaces (Figure $3 a$ ) are produced by incremental fracture advance [e.g., Ryan and Sammis,

Table 1. Description of Fractures Found in Lavas That Have Interacted With Ice

\begin{tabular}{|c|c|c|}
\hline Fracture Type & Description & Inferred Origin \\
\hline \multicolumn{3}{|c|}{ Glassy Flow Margins } \\
\hline Shards & $\begin{array}{l}\text { Small fragments of glassy lava, commonly } \\
\text { altered to palagonite; found disaggregated as } \\
\text { hyaloclastites in association with lava pillows } \\
\text { or pillow fragments. }\end{array}$ & $\begin{array}{l}\text { Rapid cooling and fracturing (granulation) of } \\
\text { lava in contact with water, in some cases } \\
\text { followed by spallation. }\end{array}$ \\
\hline Hackly fractures & $\begin{array}{l}\text { Chaotic, arcuate fractures with a range of } \\
\text { orientations and crosscutting relationships; } \\
\text { may have palagonite along fractures. }\end{array}$ & 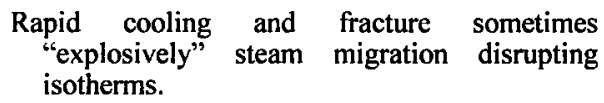 \\
\hline $\begin{array}{l}\text { Pseudopillow fractures and } \\
\text { secondary fractures }\end{array}$ & $\begin{array}{l}\text { Areuate fractures with associated small, } \\
\text { perpendicular, secondary fractures; palagonite } \\
\text { along fracture. }\end{array}$ & $\begin{array}{l}\text { Cooling by water/steam penetration into rock } \\
\text { with relatively well established isotherms that } \\
\text { become locally disrupted resulting in } \\
\text { secondary fractures. }\end{array}$ \\
\hline Sheet-like fractures & $\begin{array}{l}\text { Parallel, planar fractures extend beyond the sides } \\
\text { of an individual column, in some places } \\
\text { reaching lengths of more than } 5 \mathrm{~m} \text {; may be } \\
\text { palagonite along fracture. }\end{array}$ & $\begin{array}{l}\text { Cooling with well-established isotherms with } \\
\text { extension of wide fractures with well- } \\
\text { developed orthogonal cross cutting fractures. }\end{array}$ \\
\hline $\begin{array}{l}\text { Polygonal fractures, } \\
\text { columnar joints }\end{array}$ & $\begin{array}{l}\text { Adjacent fractures intersect to define regular } \\
\text { polygons. Normally parallel, but may fan or } \\
\text { bend. }\end{array}$ & $\begin{array}{l}\text { Cooling with well-established isotherms with } \\
\text { isotropic stress field; little or no fluid flow. }\end{array}$ \\
\hline \multicolumn{3}{|c|}{ Crystalline Flow Interior } \\
\hline $\begin{array}{l}\text { Platy fractures, sheeting } \\
\text { joints }\end{array}$ & $\begin{array}{l}\text { These fractures form overlapping plates that are } \\
\text { often closely spaced, } 0.5-4 \mathrm{~cm} \text { apart, have an } \\
\text { average breadth of about } 80 \mathrm{~cm} \text {, and break } \\
\text { around phenocrysts. Fractures tend to be } \\
\text { parallel to the flow base, except near the } \\
\text { boundary with the carapace, where they are } \\
\text { oriented parallel to the flow margin. }\end{array}$ & $\begin{array}{l}\text { Since these interior fractures paralle] flow } \\
\text { direction and occurred after the lava had } \\
\text { substantially crystallized, they are probably } \\
\text { related to late stage shear of the lava flow } \\
\text { [Bonnichsen and Kauffmann, 1987] and/or } \\
\text { microlite orientation [Walker, 1993]. }\end{array}$ \\
\hline $\begin{array}{l}\text { Broad polygonal fractures, } \\
\text { megacolumns }\end{array}$ & $\begin{array}{l}\text { Broad ( }>1 \mathrm{~m} \text { diameter) polygonal (four or five- } \\
\text { sided) joint sets cutting through flow interior. } \\
\text { Fractures break around phenocrysts. }\end{array}$ & $\begin{array}{l}\text { Late stage cooling and contraction, somewhat } \\
\text { irregular due to preexisting platy fractures; in } \\
\text { some cases, one face will have formed earlier, } \\
\text { prior to development of platy fractures. }\end{array}$ \\
\hline
\end{tabular}




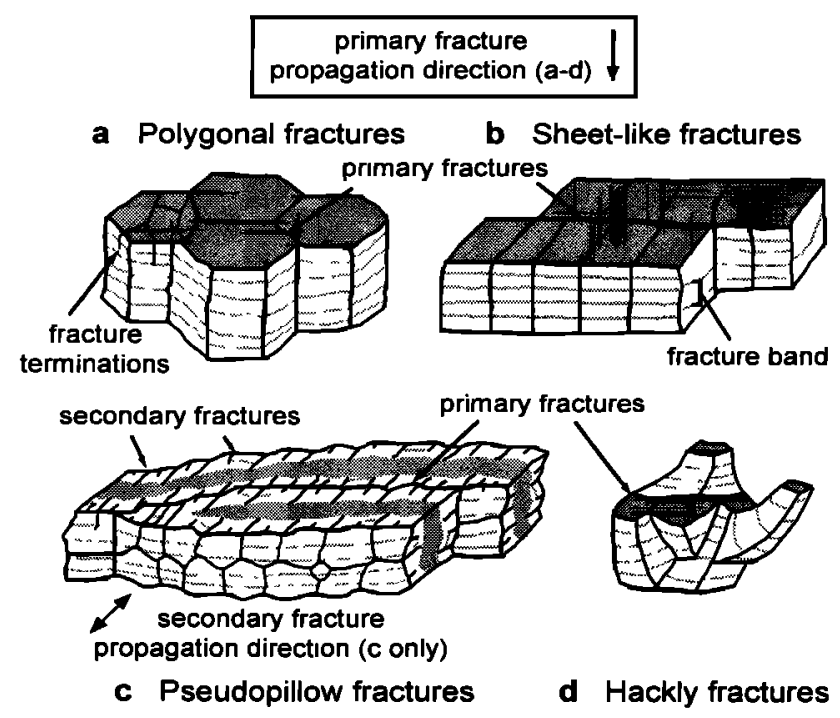

Figure 3. Sketches of fracture morphologies. (a) Polygonal fractures. (b) Sheet-like fractures. (c) Pseudopillow fractures. (d) Hackly fractures. White surfaces correspond to cooling fracture faces, with gray lines representing incremental fracture terminations. The surface between two of these fracture terminations is called a "band" or "striae". Heavy black lines represent cooling fractures. Lighter black lines represent incipient cooling fractures: in (a) these are poorly developed primary fractures; in (c) these are secondary fractures. Propagation direction for all primary fractures (a-d) is toward the bottom of the figure. Propagation directions for secondary fractures in (c) are into and out of the figure.

1978; DeGraff and Aydin, 1987; Aydin and DeGraff, 1988; DeGraff and Aydin, 1993] and range from several millimeters to several centimeters in width. In general, band width varies with column diameter; columns $4 \mathrm{~cm}$ in diameter have band widths of $0.3-1 \mathrm{~cm}$ and columns $30 \mathrm{~cm}$ in diameter have band widths of $2.5-3 \mathrm{~cm}$.

Sheet-like fractures have parallel sets of long fractures $(\leq 5$ $\mathrm{m}$ long) that are separated by up to $10 \mathrm{~cm}$. Perpendicular fractures connect adjacent long fractures producing rectangular columns (Figures $3 \mathrm{~b}$ and $4 \mathrm{c}$ ). Bands extend continuously along the length of long fractures and have widths similar to those observed in polygonal fractures. In some cases, bands on the shorter connecting fractures are wider and more arcuate than those on the adjacent long fractures (Figure $3 \mathrm{c}$ ).

Pseudopillow fractures are arcuate fractures that extend for several meters and commonly occur in roughly subparallel sets with some intersections (Figures $3 \mathrm{c}, 4 \mathrm{~d}$ and $4 \mathrm{e}$ ). Short fractures extend perpendicular to, but rarely connect, the pseudopillow fractures. Bands on the shorter fractures are oriented parallel to the pseudopillow fractures, indicating that these are secondary fractures that propagated away from the pseudopillow fractures (Figure 3c) [Watanabe and Katsui, 1976]. Mud and/or altered glass (palagonite) is commonly found in pseudopillow fractures but not in the shorter secondary fractures.

Hackly fractures intersect chaotically and form irregular angular blocks or "splinters" of rock (Figures 3d, 4f, and 4g). The angular blocks and splinters generally trend away from the flow margin or radiate from small voids at the lava flow bases. Fracture spacing ranges significantly (from tens of centimeters to $<1 \mathrm{~cm}$ ) over short distances $(<1 \mathrm{~m})$. Bands on fracture surfaces are arcuate, and their widths also vary greatly (Figure 3d). Mud and/or palagonite are commonly found along hackly fracture surfaces.

Small shards of glass (millimeters in scale) are formed by the intersection of large numbers of closely spaced fractures (Figure 4h). The glass shards are commonly altered to palagonite and are found as disaggregated sediments (hyaloclastites) in close association with lava pillows. Glass shards and hyaloclastites are rare at the lava-ice interaction localities that we studied.

Two additional types of fractures (platy and broad polygonal fractures) occur in the crystalline flow interior and, in some cases, extend $10-20 \mathrm{~cm}$ into the glassy flow margin. Platy fractures tend to be oriented parallel to the flow base, except where they approach and become oriented parallel to the flow margins. These fractures form overlapping plates that are often closely spaced, $0.5-4 \mathrm{~cm}$ apart, have an average width of about $80 \mathrm{~cm}$, and break around phenocrysts, unlike fractures in the glassy zone that propagate through phenocrysts. Broad polygonal fractures $(>50 \mathrm{~cm}$ in diameter) form poorly defined megacolumns that are common in flow interiors and may crosscut platy fractures (Figure 2).

\subsection{Large-Scale Lava Flow Morphology}

Landforms produced by lava-ice interaction at stratovolcanoes vary significantly in their morphology and size. They can be separated into three groups of landforms: (group 1) glassy margins with polygonal fractures; (group 2) glassy margins and continuous fractures; and (group 3) glassy margins with pseudopillow fractures (Figure 5).

3.2.1. Group 1 landforms: Glassy margins with polygonal fractures. Steep-walled ridge flows, smaller lava flows and one variety of dome have steep glassy flow margins with numerous polygonal fractures on the margins (Figures $5 \mathrm{a}-5 \mathrm{c}$ ). Lava flows forming steep-walled ridges (Table 2 ) can be up to $450 \mathrm{~m}$ thick and extend up to $25 \mathrm{~km}$ from the volcano's summit. Less voluminous, thinner lava flows $(\sim 20-$ $30 \mathrm{~m}$ thick) include several thinner lobes of the ridge flows. Domes are even smaller (down to $20 \mathrm{~m}$ in diameter) and include discrete bulges $(\approx 4 \mathrm{~m}$ high and $\approx 8 \mathrm{~m}$ wide) connected by thinner fingers of lava. These flows ranged from andesite to rhyolite in composition.

The width of the glassy margins ranges up to $5 \mathrm{~m}$ in a few thick lava flows ( $>100 \mathrm{~m}$ thick) and to $<2 \mathrm{~m}$ in thinner flows and domes $(<50 \mathrm{~m}$ thick). Flow fronts of several of the ridge flows have glassy zones that extend up to $12 \mathrm{~m}$ inward [Lescinsky and Sisson, 1998, Figure 2]. As flow thickness decreases, glassy flow surfaces become more common; almost all flows or flow lobes of $\leq 10 \mathrm{~m}$ thickness have glassy flow surfaces. Where preserved, the upper portions and surfaces of lava flows $>30 \mathrm{~m}$ thick are crystalline, oxidized, and vesicular. Flow bases tend to be somewhat less glassy than flow margins, and basal breccias are either thin or absent.

Lava flows forming steep-walled ridges have $2-5 \mathrm{~m}$ thick basal zones of glassy, broad $(30-40 \mathrm{~cm}$ in diameter) and vertically oriented columns (Figures 2 and 5a). Basal columns in smaller flows and domes are not significantly broader $(15-20 \mathrm{~cm}$ in diameter) than the associated marginal columns $(\sim 10 \mathrm{~cm}$ in diameter). Hackly, pseudopillow, and 

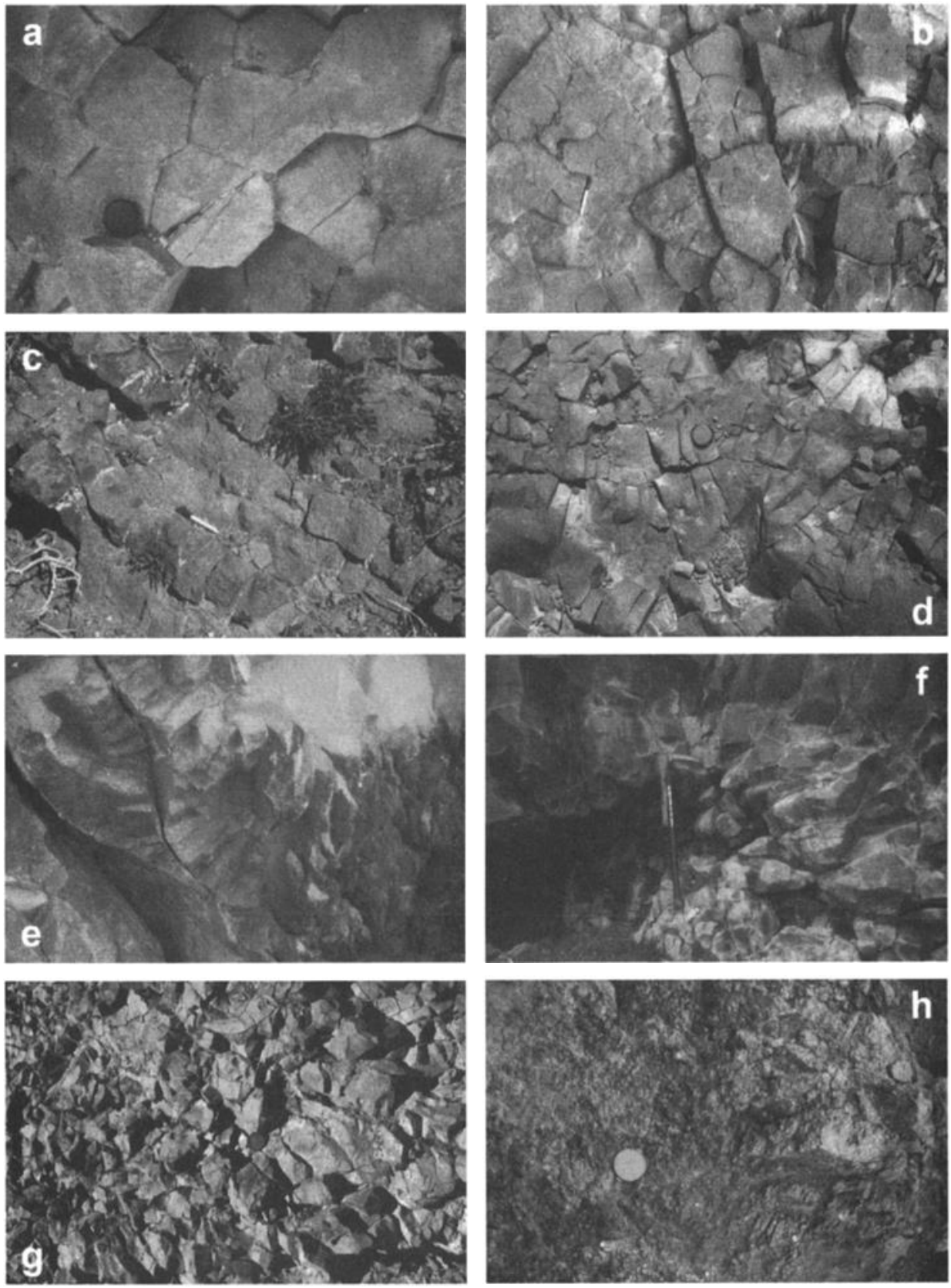

Figure 4. Photographs of fracture types produced during lava-ice interaction. (a) and (b) Polygonal fractures near Yakima Point, Burroughs Mountain flow, Mount Rainier, Washington. The columns formed by the fractures in Figure $4 \mathrm{a}$ are quite regular and have an average diameter of $-10 \mathrm{~cm}$. Figure $4 \mathrm{~b}$ was taken several meters away and represents a point $30-50 \mathrm{~cm}$ farther inward from the outer flow margin. Note that the columns are much broader $(20-30 \mathrm{~cm}$ in diameter), are less regular, and show the termination of fractures that form narrower columns. (c) Sheet-like fractures trending diagonally across the picture from Kokostick Butte, South Sister, Oregon. Smaller cross-cutting fractures are also visible. (d) Pseudopillow fracture at the center of the photo with an irregular arcuate trend and secondary fractures extending perpendicular from it. Figure $4 \mathrm{~d}$ is from the glassy flow surface of the Mazama Ridge flow, Mount Rainier, Washington, visible in Figure 2. (e) Pseudopillow fractures, left of center, in a pillow lobe in Spray Park, Mount Rainier, Washington. Note the darker, rough outer surface of the pillow lobe on the right side. (f) Hackly fractures radiating from the right side of a cave at the base of a lava flow next to Nisqually Glacier, Mount Rainier, Washington. Presumably, the cave was produced by the melting of an ice block that had been covered by the lava flow. (g) Hackly, intersecting fractures in a Grande Ronde Basalt flow along the Tieton River, Washington. (h) Gradational contact between disaggregated hyaloclastite on left and shards in coherent lava on right at Bláhnúkur, Torfajökull, Iceland. Fractures in Figures $4 \mathrm{a}-4 \mathrm{e}$ are viewed perpendicular to the cooling surface, propagation was into the photo. Fractures in Figures $4 \mathrm{f}$ and $4 \mathrm{~g}$ are viewed oblique to the cooling surface; propagation was toward the right of the photo and inward. Lens cap in Figures $4 \mathrm{a}, 4 \mathrm{~d}, 4 \mathrm{~g}$ and $4 \mathrm{~h}$ is $5.2 \mathrm{~cm}$ in diameter. Pen in Figures $4 \mathrm{~b}$ and $4 \mathrm{c}$ is $14 \mathrm{~cm}$ long. Ice axe in Figure $4 \mathrm{f}$ is $\sim 90 \mathrm{~cm}$ long. Field of view in Figure $4 \mathrm{e}$ is $\sim 150 \mathrm{~cm}$. 


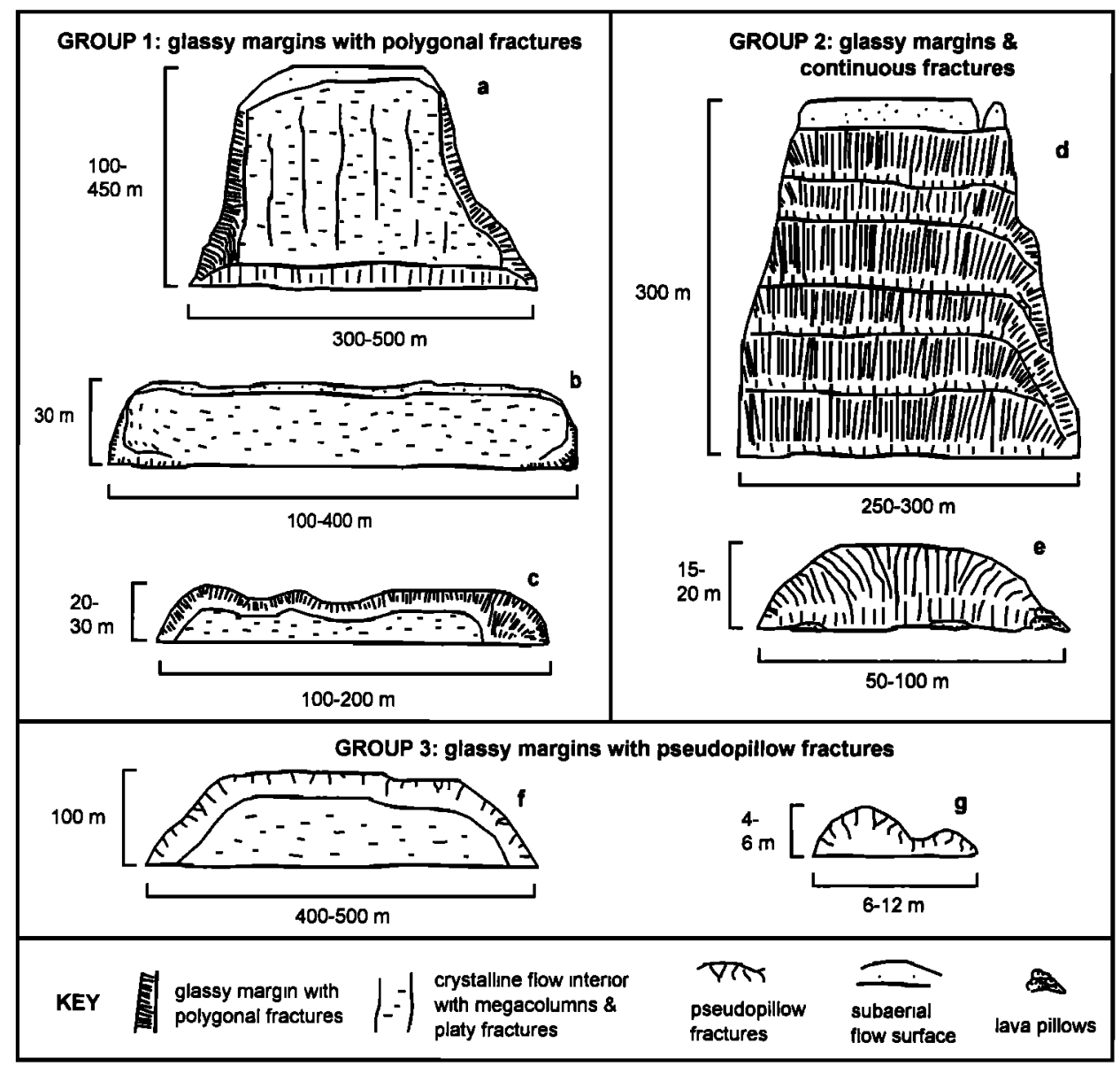

Figure 5. Idealized sketches showing the structural cross-sections and fracture distributions in different landforms associated with lava and ice interaction at stratovolcanoes. Group 1 landforms: (a) ridge-forming lava flow; (b) smaller lava flow; and (c) polygonally jointed subglacial dome. Group 2 landforms: (d) flat-topped mountain [after Mathews, 1951]; and (f) esker-like lava flow. Group 3 landforms: (f) subglacial dome with pseudopillow fractures; and $(\mathrm{g})$ pillow lobe flow.

sheet-like fractures occur in some places on the flow surfaces of thinner lava flows, flow lobes, and small domes and are also found associated with voids at flow bases (Figures $4 \mathrm{f}$ and 6). Hackly fractures occur closest to the flow margin or surface, and pseudopillow, sheet-like, and polygonal fractures occur progressively inward toward the flow interior (Figure 6). Also in the smaller flows and domes, there is a zone of massive glass (roughly $1 \mathrm{~m}$ wide) with broad fractures between the marginal columns and the crystalline flow interior (Figures $5 \mathrm{~b}$ and $5 \mathrm{c}$ ).

The flow interiors of all three landform types are massive, are crystalline, and commonly have platy fractures and poorly formed, broad columns (Figures 2 and $5 \mathrm{a}-5 \mathrm{c}$ ). Platy fractures in the flow interior are oriented concentric to the shape of the lava flow at its margins (i.e., near vertical, Figure 5b) and are absent or poorly developed at the center of the flow.

3.2.2. Group 2 landforms: Glassy margins and continuous fractures. This group is characterized by polygonal (and rarely hackly) fractures that extend through the entire flow thickness. The group includes flat-topped lava mountains (composed of multiple lava flows; Figure 5d) and sinuous "esker-like" lava flows (Figure 5e). These landforms are composed of relatively thick lava flows with steep flow margins (Figures 5a and 5f). Polygonal fractures in the lava flows form narrow columns in an upper "entablature" zone and broad columns in a lower "colonnade" zone. In the esker-like lava flows the entablature zones are $\sim 80 \%$ of the entire flow thickness and have columns $15-20 \mathrm{~cm}$ in diameter; columns in the colonnade are $40-60 \mathrm{~cm}$ in diameter.

Along the margins of these landforms, column orientations change from vertical to subhorizontal, and the flows are locally glassy (Figures $5 \mathrm{~d}$ and $5 \mathrm{e}$ ). Several of the esker-like lava flows have discrete lava pillows or flattened ellipsoidal pillow lobes (6-15 m across and about a meter thick) along their margins and scoriaceous flow bases. Hyaloclastites are absent except for thin layers of interstitial hyaloclastites associated with pillows.

3.2.3. Group 3 landforms: Glassy margins with pseudopillow fractures. These landforms have subparallel pseudopillow fractures in the glassy marginal zone and include lava domes (Figure $5 \mathrm{f}$ ) and pillow lobe flows (Figure $5 \mathrm{~g}$ and Table 2). The pseudopillow fractures are filled with brown mud/palagonite and extend inward 3-4 m before giving way to a roughly $2 \mathrm{~m}$ thick zone of massive, irregularly jointed glass (Figure 5f). In the pillow lobes, pseudopillow fractures extend up to $1 \mathrm{~m}$ and commonly have altered bread- 


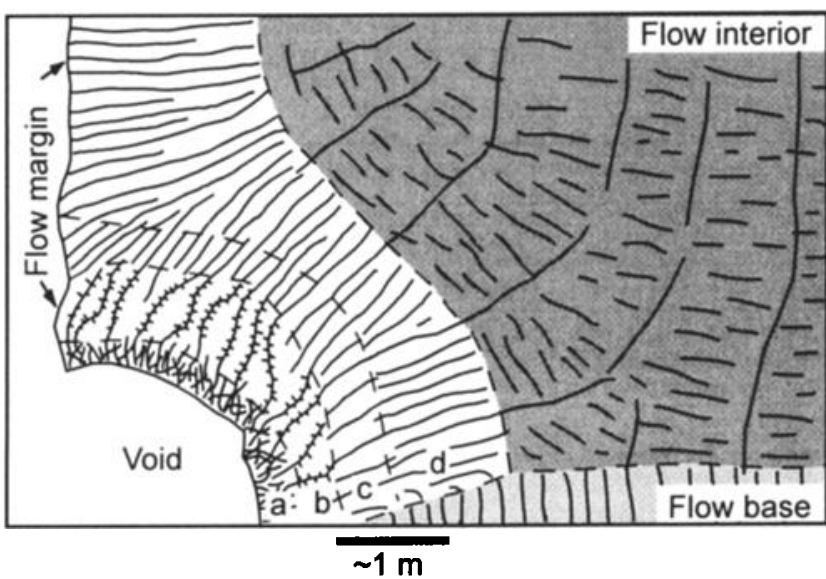

Figure 6. Idealized sketch showing progression of fracture types from a void at the base of lava flow to the crystalline flow interior. Different fracture types are separated by dashed line. Labels are a, hackly fractures; b, pseudopillow fractures; c, sheet-like fractures; and d, polygonal fractures. The transition between fracture types is gradational. Wider polygonal fractures are found at the flow base and irregular, broad polygonal fratures and platy fractures are found in the flow interior.

crust like surfaces that form rinds several centimeters thick (Figure 4e). Both domes and pillow lobes have crystalline and platy jointed flow interiors, although this is less pronounced in the thinner pillow lobes.

\section{Discussion}

\subsection{Lava Flow Emplacement and Morphology}

The majority of lava flows and landforms studied are consistent with observations of lava flows in ice trenches. Group 1 landforms have glassy margins with polygonal fractures, are commonly thick, and have steep margins with subhorizontal columns due to flow confinement and quenching against ice walls [Mathews, 1952a; Lescinsky and Sisson, 1998]. Flat-topped mountains (group 2) also form by ice confinement with successive lava flows filling sustained glacial voids [Mathews, 1951].

In addition to evidence of flow confinement, several of the landforms show evidence of substantial amounts of ponded water. Esker-like flows (group 2) have pillows and localized areas of vesiculation at their bases, indicating that these lavas traveled through shallow water and/or saturated sediments. Group 3 domes have abundant pseudopillow fractures that form due to water infiltration [Watanabe and Katsui, 1976; Yamagishi, 1991a, 1991b]. The final landforms, pillow lobe flows (group 3), also have pseudopillow fractures but show no evidence of confinement.

We can use the evidence of flow confinement, abundant water, and landform size to graphically separate the features studied (Figure 7). End-members show evidence of either lava flow confinement or of emplacement in water. The confined flow end-member includes (in order of decreasing size): flat-topped mountains (group 2), steep-walled ridge flows, smaller lava flows, and domes (group 1). In between

Table 2. Types and Locations of Lava-Ice Interaction Landforms Studied in the Field

\begin{tabular}{|c|c|}
\hline Landform type & Examples \\
\hline & Group 1: Glassy Margins With Polygonal Fractures \\
\hline Steep-walled ridge flows & $\begin{array}{l}\text { Numerous examples at Mount Rainier, Washington, most notably: Emerald Ridge flow } \\
\left(46^{\circ} 48.23^{\prime} \mathrm{N}, 121^{\circ} 52.08^{\prime} \mathrm{W}\right) ; \mathrm{Mazama} \text { Ridge flow }\left(46^{\circ} 47.98^{\prime} \mathrm{N}, 121^{\circ} 42.78^{\prime} \mathrm{W} \text {, area }\right. \\
\text { visible in Figure } 2 ; 46^{\circ} 45.43^{\prime} \mathrm{N}, 121^{\circ} 39.68^{\prime} \mathrm{W} \text {, terminus of flow); and Burroughs } \\
\text { Mountain flow }\left(46^{\circ} 54.43^{\prime} \mathrm{N}, 121^{\circ} 34.62^{\prime} \mathrm{W}\right) ; \text { Kulshan Ridge flow Mount Baker, } \\
\text { Washington }\left(48^{\circ} 49.66^{\circ} \mathrm{N}, 121^{\circ} 41.21^{\prime} \mathrm{W}\right) ; \text { flow at piedmont lobe of Drift River Glacier } \\
\text { Mount Redoubt, Alaska }\left(60^{\circ} 32.40^{\prime} \mathrm{N}, 152^{\circ} 45.90^{\prime} \mathrm{W}\right) \text {; flows at Mount Rainier are } \\
\text { andesites and dacites [Sisson and Lanphere, 1997]. }\end{array}$ \\
\hline Smaller lava flows & $\begin{array}{l}\text { Moraine Lake flow }\left(44^{\circ} 03.45^{\prime} \mathrm{N}, 121^{\circ} 46.03^{\prime} \mathrm{W}\right) \text { and Kokostick Butte }\left(44^{\circ} 01.38^{\prime} \mathrm{N} \text {, }\right. \\
\left.121^{\circ} 47.88^{\prime} \mathrm{W}\right) \text {, South Sister, Oregon; Whitewater Glacier lower dacite }\left(44^{\circ} 42.43^{\prime} \mathrm{N},\right. \\
\left.121^{\circ} 48.04^{\prime} \mathrm{W}\right) \text {, Mount Jefferson, Oregon; several thinner lobes of the ridge flows listed } \\
\text { above, most notably above Heather Meadows }\left(48^{\circ} 50.51^{\prime} \mathrm{N}, 121^{\circ} 41.32^{\prime} \mathrm{W}\right) \text {, Mount } \\
\text { Baker, Washington; flows are andesites and dacites [Taylor et al., 1987; Conrey, 1991]. }\end{array}$ \\
\hline \multirow[t]{2}{*}{ Domes } & $\begin{array}{l}\text { Wikiup Plain }\left(44^{\circ} 03.09^{\prime} \mathrm{N}, 121^{\circ} 47.46^{\prime} \mathrm{W}\right) \text { and west side }\left(44^{\circ} 03.45^{\prime} \mathrm{N}, 121^{\circ} 46.03^{\prime} \mathrm{W}\right) \text {, } \\
\text { South Sister, Oregon; Glacier Creek }\left(44^{\circ} 05.13^{\prime} \mathrm{N}, 121^{\circ} 49.37^{\prime} \mathrm{W}\right) \text {, North Sister, Oregon; } \\
\text { flows are rhyodacites and rhyolites. }\end{array}$ \\
\hline & Group 2: Glassy Margins and Continuous Fractures \\
\hline Flat-topped lava mountains & $\begin{array}{l}\text { The Table }\left(49^{\circ} 53.69^{\prime} \mathrm{N}, 123^{\circ} 00.83^{\prime} \mathrm{W}\right) \text {, near Garibaldi Lake, British Columbia; flows are } \\
\text { andesites [Mathews, } 1951] \text {. }\end{array}$ \\
\hline \multirow[t]{2}{*}{ Esker-like lava flows } & $\begin{array}{l}\text { Several examples }\left(50^{\circ} 03.90^{\prime} \mathrm{N}, 123^{\circ} 07.93^{\prime} \mathrm{W}\right) \text { in Cheakamus River valley near Garibaldi } \\
\text { Lake, British Columbia; flows are basalts [Mathews, 1958]. }\end{array}$ \\
\hline & Group 3: Glassy Margins With Pseudopillow Fractures \\
\hline Domes & $\begin{array}{l}\text { Three small buttes }\left(40^{\circ} 30.65^{\prime} \mathrm{N}, 121^{\circ} 13.06^{\prime} \mathrm{W} ; 40^{\circ} 30.13^{\prime} \mathrm{N}, 121^{\circ} 13.27^{\prime} \mathrm{W} ; 40^{\circ} 29.13^{\prime} \mathrm{N} \text {, }\right. \\
121^{\circ} 13.04 \text { 'W), Caribou Wilderness east of Lassen, California; domes are andesites and } \\
\text { basaltic andesites [Guffanti et al., 1996]. }\end{array}$ \\
\hline Pillow-lobe flows & $\begin{array}{l}\left.\text { Spray Park (46 } 46^{\circ} 5.39^{\prime} \mathrm{N}, 121^{\circ} 48.67^{\prime} \mathrm{W}\right) \text {, Mount Rainier, Washington; NE of Park Butte } \\
\left(44^{\circ} 43.96^{\prime} \mathrm{N}, 121^{\circ} 47.93^{\prime} \mathrm{W}\right) \text {, Mount Jefferson, Oregon; flows are basaltic-andesite to } \\
\text { andesite [Conrey, 1991; Sisson and Lanphere, 1997]. }\end{array}$ \\
\hline
\end{tabular}




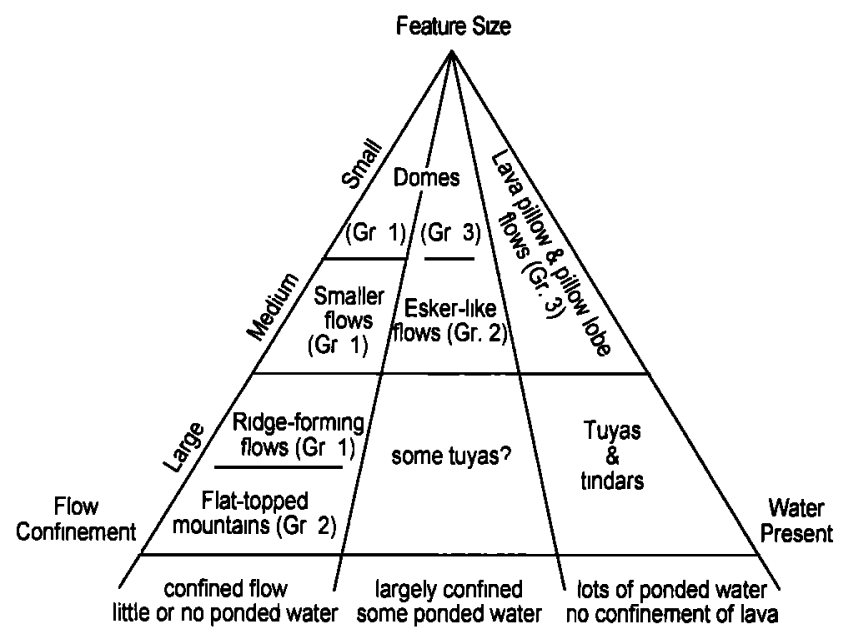

Figure 7. Qualitative diagram separating landforms produced during lava and ice interaction, based on landform size and the presence of evidence for flow confinement or subaqueous emplacement. End-members that show evidence of flow confinement (great flow thickness, steep lava flow margins with horizontal fractures) but no evidence of ponded water (pseudopillow fractures, shards, hyaloclastites, or lava pillows) were likely emplaced in trenches and voids in thin glaciers on the flanks of stratovolcanoes. End-members that show evidence of ponded water but no evidence of lava flow confinement were likely emplaced in englacial lakes. Intermediate landforms showing evidence of both were likely emplaced in small water-filled glacial voids or voids with shallow water. Landform groups listed (groups 1-3) are discussed in the text.

the two end-members, esker-like flows (group 2) and domes (group 3) show evidence of both flow confinement and emplacement in water.

Although examples of lava flows emplaced in water (englacial lakes) are rare in the Cascades (include only pillow lobe flows, group 3, and the tindars of Lone Butte and Crazy Hills, southern Washington [Hammond, 1987]), they are common in Iceland, Antarctica, and the Tuya-Teslin region of Canada and are included in Figure 7. These landforms, composed of large quantities of hyaloclastites, lava pillows and massive lava, reflect the shape of the water-filled voids in which they formed due to confinement of the hyaloclastite beds [e.g., Smellie, 2000], rather than confinement of lava flows. At the larger end of the size spectrum, tuyas and tindars form mountains up to $5 \mathrm{~km}$ across and $600 \mathrm{~m}$ high [Mathews, 1947; Bemmelen and Rutten, 1955]. Smaller, mound-forming or esker-like bodies may reach more than 1 $\mathrm{km}$ across and $200 \mathrm{~m}$ high [Walker and Blake, 1966; Smellie and Skilling, 1994].

Since the development of englacial lakes is limited to topographic depressions or thick, impermeable glaciers, we can use Figure 7 as a crude discriminator of ice thickness. Landforms composed of confined lavas correspond to thin glaciers $(<150 \mathrm{~m}$ thick), and landforms composed of lavas emplaced in water correspond to thick glaciers $(>>150 \mathrm{~m}$ thick).

Lava flows emplaced on top of glaciers are not well represented in the geologic record and appear as monolithologic breccias and abruptly terminated lava flows [Mathews, 1952b; Bemmelen and Rutten, 1955; Wright, 1980;
Scott, 1987]. These are not included in Figure 7 for this reason but may provide evidence of lava-ice interaction in combination with other observations.

\subsection{Fracture Production and Cooling Rate}

Fractures in the glassy flow margins reflect the cooling history of the lava during flow advance and lava-ice interaction, rather than postemplacement. These fractures formed incrementally by thermal contraction, producing the bands on their faces (Figure 3) and propagated inward as the flows cooled [e.g., Ryan and Sammis, 1978; Long and Wood, 1986; DeGraff and Aydin, 1987; Aydin and DeGraff, 1988; DeGraff and Aydin, 1993]. Since fracturing followed the solidification front, the fractures tend to be oriented perpendicular to the closest flow surface or margin [e.g., Long and Wood, 1986; Aydin and DeGraff, 1988]. The abrupt transition in fracture type and increase in crystallinity at the boundary with the flow interior suggest that the flow margins formed a rigid shell around the still moving flow interior [Lescinsky and Sisson, 1998]. Examples of fractures formed after flow emplacement include those in columnar basalts that penetrate the majority of the flow thickness, experience only gradual change in spacing, and have predominantly subvertical orientations [e.g., Long and Wood, 1986; DeGraff and Aydin, 1993].

The fractures observed in lava flows that have interacted with ice show an inward progression in form (Figure 6). At flow margins, fractures are irregular and closely spaced (shard-forming and hackly fractures), and toward flow interiors, fractures are regular and more widely spaced (sheetlike and polygonal fractures). This progression in fracture spacing and regularity corresponds to decreasing cooling rates inward from the flow margins (Figure 6) [Long and Wood, 1986; Reiter et al., 1987; DeGraff et al., 1989; DeGraff and Aydin, 1993; Budkewitsch and Robin, 1994]. Substantial changes in cooling rate result from variations in cooling mechanisms. Cooling by radiation and atmospheric convection at a lava flow surface is slower than convective cooling by water and steam penetrating the flow [Saemundsson, 1970; Hardee, 1980; Long and Wood, 1986; DeGraff and Aydin, 1993]. This difference in cooling rate produces zones of regular, polygonal fractures (colonnade zone) and zones of irregular, narrower hackly fractures (entablature) in columnar basalts. Convecting water in subaqueous environments cools lava even more rapidly and causes granulation and the formation of glass shards [e.g., Batiza and White, 2000]. The relationship between cooling rate and fracture spacing/type is presented graphically (Figure 8 ), with the lowest cooling rates associated with subaerial emplacement (no glacial ice or meltwater) and the highest cooling rates associated with subaqueous emplacement (such as within an englacial lake).

Fracture spacing is controlled largely by the fracture depth (striation width) [Lachenbruch, 1961; Nemat-Nasser and Oranratnachai, 1979], which is a function of thermal gradient [Ryan and Sammis, 1978; DeGraff and Aydin, 1993; Grossenbacher and McDuffie, 1995]. Large thermal gradients result in narrow striations and closer fractures. Repeated narrow striations and sustained high thermal gradients indicate a constant cooling rate at the solidification front. If the cooling rate at the solidification front were to decrease, we would expect to see a change to smaller thermal 


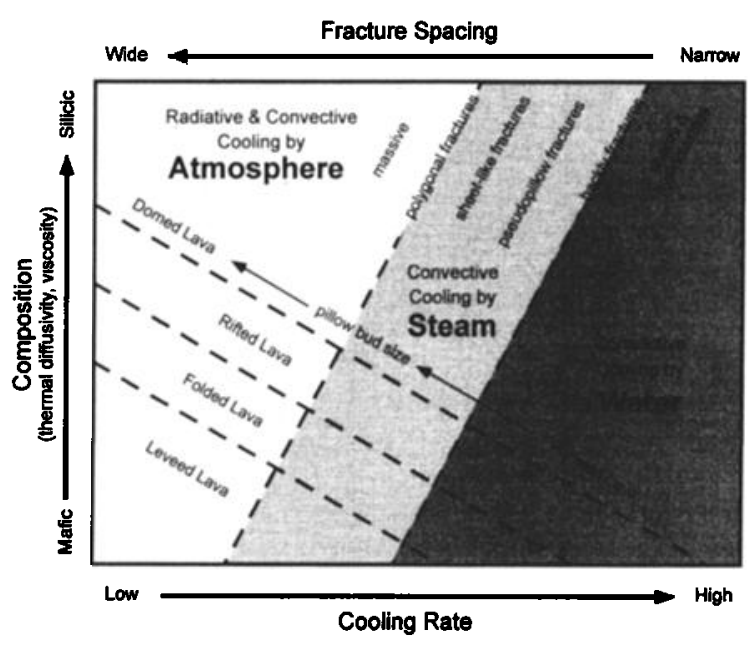

Figure 8. Qualitative model relating fracture type to cooling rate, cooling mechanism, and lava composition. Fracture spacing increases, and fracture morphologies become more regular as flow cooling rates decrease [e.g., Long and Wood, 1986; DeGraff and Aydin, 1993], resulting in the sequence from shards at high cooling rates to polygonal fractures at low cooling rates. Cooling rates are sensitive to both cooling mechanism and flow composition. Cooling by radiation and atmospheric convection at a lava flow surface (no shading) is slower than convective cooling by steam (light shading) or by water (dark shading) penetrating the flow [e.g., Hardee, 1980; Long and Wood, 1986]. Cooling of lava is largely a function of the lava's thermal diffusivity. Since silicic magmas have larger thermal diffusivities, they can cool more rapidly mafic magmas [Gregg and Fink, 1996]. Fracture spacing is also controlled by compositionally dependant material properties (Young's modulus, Poisson's ratio, and thermal expansivity) [Nemat-Nasser and Oranratnachai, 1979] that result in more closely spaced fractures in rhyolites than in basalts. Analog studies have demonstrated that different surface morphologies (levees, folds, rifts, and pillows) are produced as a function of cooling rate, eruption rate, and lava flow viscosity and/or yield strength [Fink and Griffiths, 1990; Griffiths and Fink, 1997]. Studies of natural lavas have found that the size of individual pillows increases with increasing viscosity [Walker, 1992].

gradients, wider striations, and more widely spaced fractures (Figures $4 \mathrm{a}$ and $4 \mathrm{~b}$ ).

Lava composition also plays an important role. Higher thermal diffusivities for silicic magmas (relative to mafic magmas) enable more rapid cooling and result in a compositional variation between cooling rate and cooling mechanism (Figure 8) [Gregg and Fink, 1996]. Silicic magmas also have lower values of Young's modulus and Poisson's ratio and higher thermal expansivity, which all tend to enable closer fracture spacing [Nemat-Nasser and Oranratnachai, 1979]. This relationship is observed in the field with narrower spacing of polygonal joints in side margins of rhyolitic lavas $(2-6 \mathrm{~cm})$ than in andesitic or basaltic lavas $(5-10 \mathrm{~cm}$ and $>10 \mathrm{~cm}$, respectively).

Quantitatively, the relationships between fracture spacing/type, cooling rate, and composition remain poorly constrained. Analog models of cyclic fracturing have employed desiccation contraction rather than thermal contraction [Corte and Higashi, 1964; Müller, 1998a, 1998b;
Hull and Caddock, 1999]. However, these approaches rely on material properties that are poorly characterized (i.e., glass transition temperature, fracture toughness, Young's modulus, Poisson's ratio). A promising approach would be to use relaxation geospedometry to measure the cooling rates of natural glassy samples from different fracture types [Wilding et al., 1996, 2000] and to develop an empirical relationship.

Cooling rates for different fracture types could also be constrained using the relationship between cooling rate and lava flow surface morphology (Figure 8). Experimental studies have demonstrated that different surface morphologies (levees, folds, rifts, and pillows) are produced as a function of cooling rate, eruption rate, and lava flow viscosity and/or yield strength [Fink and Griffiths, 1990; Griffiths and Fink, 1997; Fink and Griffiths, 1998]. Also, studies of natural lavas have found that the size of individual pillows increases with increasing viscosity [Furnes et al., 1980; Fridleifsson et al., 1982; Walker, 1992].

It is apparent that lava flows that interact with ice have complex and heterogeneous cooling histories. In contrast, models of lava flow cooling only consider the average heat flux from an entire flow [e.g., Jaeger, 1968; Hardee, 1980; Dragoni, 1989; Manley, 1992; DeGraff and Aydin, 1993; Hon et al., 1994; Keszthelyi and Denlinger, 1996]. Relating cooling rate and fracture type would allow construction of more accurate cooling histories for these lava flows. Improved cooling histories would make it possible to determine heat fluxes and meltwater production rates over time. This would enable predictions of the potential extent of flooding during lava-ice interaction, as highlighted by Smellie [2000].

\subsection{Reconstructing Eruption History and Paleoenvironments}

We can use the characteristic fractures and landforms produced during lava and ice interaction as indicators of glacial thickness and location during the eruption. The presence of glassy or crystalline flow surfaces can be used to map out subglacial flow and fracture morphologies can be used to indicate where water may have accumulated and whether it accumulated in significant amounts (i.e., forming ponds or lakes). By reconstructing past cases of lava-ice interaction we can determine situations where meltwater production and accumulation are most common and therefore better assess where it may occur during future eruptions at glaciated volcanoes. Examples of such reconstructions are presented below.

4.3.1. Reconstruction of Mazama Ridge lava eruption, Mount Rainier, Washington. The Mazama Ridge lava at Mount Rainier is a high silica andesite-dacite flow that was erupted $\sim 90 \mathrm{kyr}$ ago [Sisson and Lanphere, 1998, available at http://www.geosociety.org/pubs/ft1998.htm]. It extends down the southern flank of the volcano to the Tatoosh Range and then east along the south wall of Stevens Canyon, where it forms several lava benches that coincide with valley confluences (Figure 9a). The abundance of glass and welldeveloped fractures along the lava flow margins and terminus makes this flow a good candidate for reconstructing the extent of the syneruptive glaciers.

The majority of lava and ice contact features crop out along the Mazama Ridge flow margin exposed in Stevens Canyon, indicating that a large glacier was present at the time 

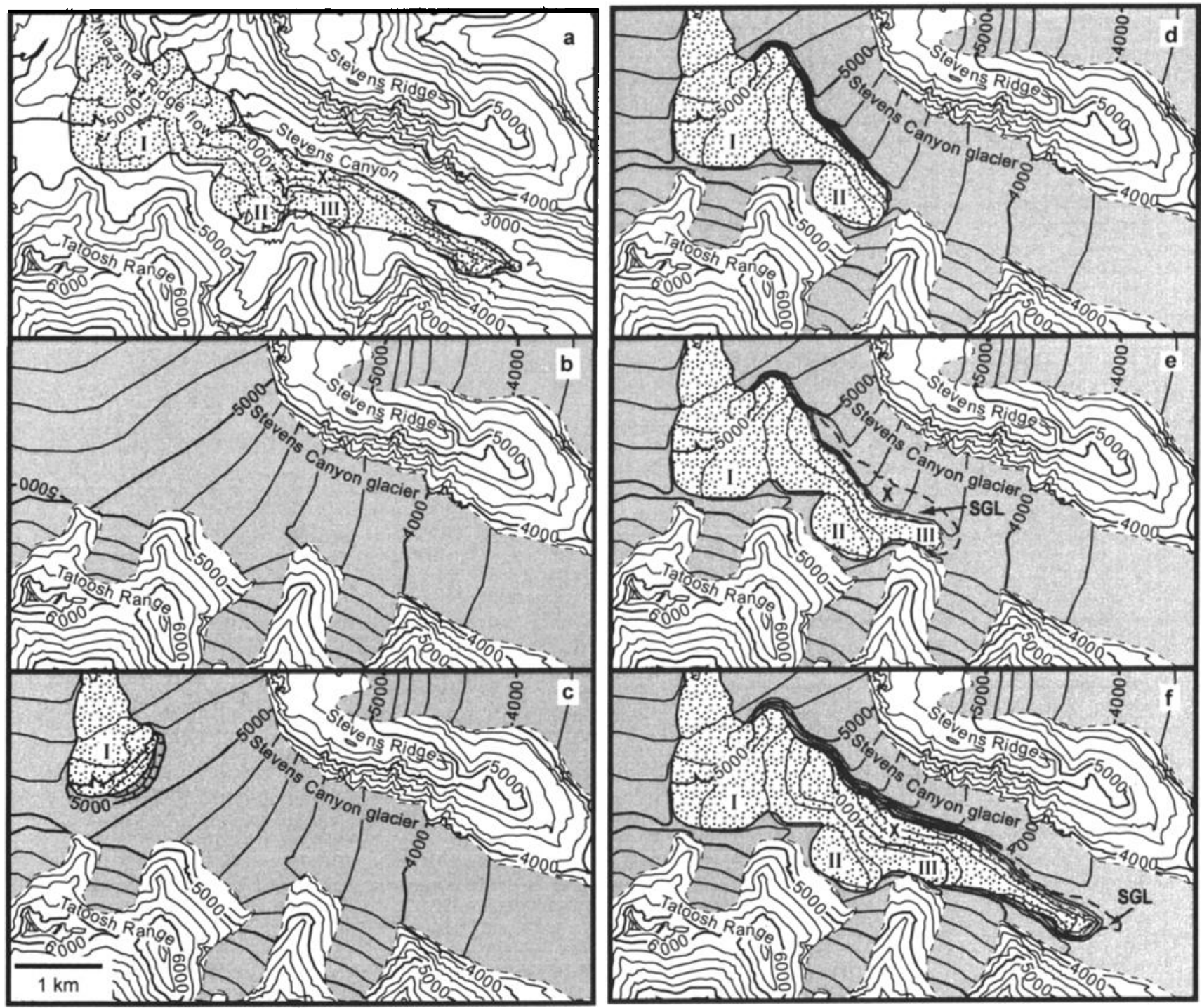

Figure 9. Reconstruction of Mazama Ridge flow (stippled area) and syneruptive glaciers (shaded areas) on the south flank of Mount Rainier. Contours are in feet. Dashed lines in Figures $9 \mathrm{e}$ and $9 \mathrm{f}$ indicate the extension of lava beneath the ice (SGL, subglacial lava). (a) Present topography [based on U.S. Geological Survey, 1971] and extent of lava flow. Lava benches are marked by "I," "II," and "III." An area of sloping lava near the head of Stevens Canyon is marked by "X." (b) Preeruptive Stevens Canyon glacier as reconstructed using evidence of lava-ice interaction discussed in text. Successive stages in flow advance and bench formation as lava intersects confluence with tributary glaciers from the (c) Sunbeam Creek, (d) Unicorn Creek, and (e) Maple Creek drainages. (f) Extent of the Mazama Ridge flow and Stevens Canyon glacier at the end of the eruption.

of the eruption. The preserved glassy and fractured sloping surface of the lava flow at the head of Stevens Canyon (Figure 9a) is consistent with subglacial flow and can be used to estimate the minimum ice thickness. The lava flow benches consist of thicker portions of the flow that have flat tops and steep scarps at their downflow boundaries. These benches probably represent sites where lava ponded before erosional channels developed and allowed continued downvalley flow. At the end of the Mazama Ridge lava a spectacular wall of lava colurnns indicates that the flow ponded against ice in a way analogous to the bench formations up slope. We can therefore use the height of the lava benches and the flow terminus wall as additional evidence of the glacial ice thickness.
Combining the different measures of the ice thickness (up to $300 \mathrm{~m}$ thick), we can extrapolate the distribution of the preeruption glaciers within Stevens Canyon and the adjacent drainages (Figure 9b). Prior to and during the eruption, voids and channels were eroded along the margins of the Stevens Canyon glacier allowing the lava to flow forward. Pauses in lava advance and bench formation occurred when these channels slowly eroded across intersecting tributary glaciers (Figures 9c-9f). This process probably involved a combination of surficial and subglacial water flow, undercutting of the glacier walls and limited subglacial flow (Figure 9e). The total meltwater produced during the eruption was estimated to be $-0.35 \mathrm{~km}^{3}$ by determining the volume of ice removed during the eruption; this calculation was made 


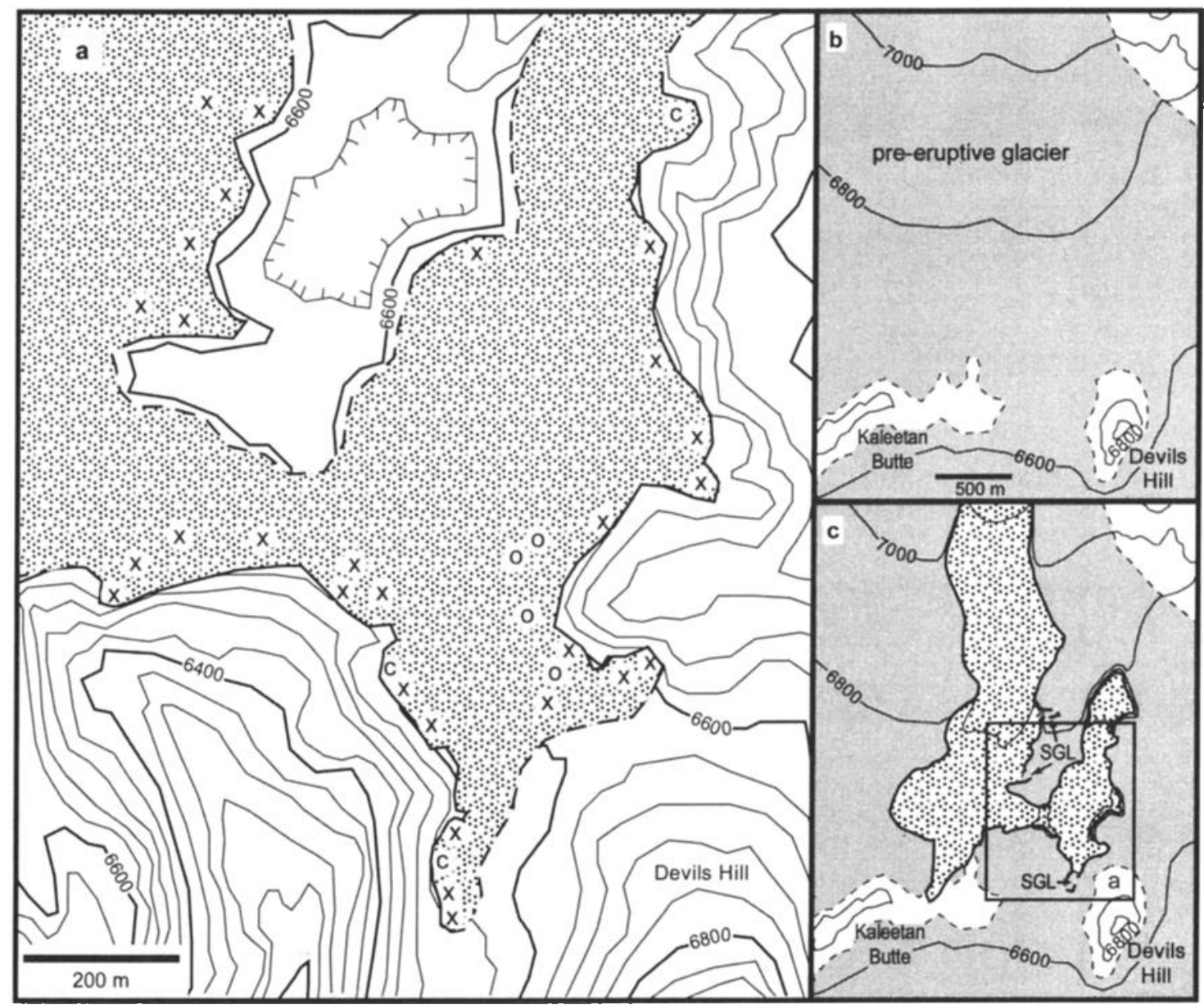

Figure 10. Reconstruction of Pleistocene andesite flow (stippled area) and syneruptive glacier (shaded area) on the south flank of South Sister, Oregon. Contours are in feet. (a) Current topography [based on U.S. Geological Survey, 1988] and extent of flow. Dashed lines indicate the inferred boundary of flow. Crosses, quench features (glass and fractures) associated with lava-ice interaction; circles, oxidized, vesicular flow surface indicative of subaerial emplacement; $c$, cave at lava flow base (such as in Figures $4 f$ and 6 ), presumably caused by melting of ice that had been covered by lava. (b) Preeruptive glacier as reconstructed using field evidence in Figure 10a. Devils Hill and Kaleetan Butte formed topographic highs that likely rose above the glacier. (c) As the lava flow reached these two topographic barriers, it was deflected to the east and north. Several small offshoots of the lava flow extended a short distance under the ice (SGL, subglacial lava). The box shows the location of Figure 10a.

using an assumed preeruption subglacial topography (not shown; based on field estimates of lava flow thickness and modern topography in Figure 9a), the estimated preeruption glacial topography (Figure $9 \mathrm{~b}$ ), and the estimated posteruption glacial topography (Figure $9 \mathrm{f}$ ). This volume is a minimum estimate since not all glacial melting will have occurred in contact with the lava flow. Melting was probably episodic, with pauses during bench formation and rapid melting associated with renewed lava advance. This behavior would have resulted in sudden pulses of water downstream that may have caused floods or debris flows, such as those documented for the more recent geologic history [Scott et al., 1995].

4.3.2. Reconstruction at South Sister Volcano, Oregon. The second reconstruction is for a Pleistocene andesite lava flow [Taylor et al., 1987] at South Sister, Oregon. This flow extends down the south flank of the volcano in the Moraine Lake region and bends eastward at the preeruptive topographic highs of Kaleetan Butte and Devils Hill.
Abundant lava and ice contact features are exposed around the margins of this flow (Figure 10a).

The South Sister lava flow is considerably thinner (30-40 $\mathrm{m}$ thick) than the Mazama Ridge flow. Hackly fractures radiate outward from several caves at the flow base (Figure 10a), suggesting that the lava overrode blocks of ice. Pseudopillow and sheet-like fractures occur along the base of several small flow lobes (5-6 $\mathrm{m}$ across) that extend downhill, away from the main lava body (Figure 10a). The flow lobes have columnar and sheet-like fractures on their upper surfaces indicative of subglacial emplacement. The thickness of these subglacial lobes was used to estimate the minimum ice thickness adjacent to the flow.

At several points, the lava flow surface appears to have cooled subaerially (Figure 10a). It is scoriaceous, crystalline and oxidized, similar in appearance to other nearby andesite flows that show no evidence of lava and ice interaction. Below these apparently subaerial lavas, the flow margins are 
steep and exhibit ice contact features. We can use this zone of transition from subaerial to subglacial emplacement to locate the upper surface of the glacier at the time of the eruption.

The field evidence lets us reconstruct the glacier that filled the depression between the flank of South Sister and Kaleentan Butte/Devils Hill dưring the eruption (Figure 10b). Lava flowed down a channel eroded through this glacier and slowed when it reached the gentler slope of the depression. As the meltwater channel became more poorly defined, small lava lobes undercut the glacier and flowed short distances under the ice (Figure 10c). Some meltwater flowed over and accumulated at the base of these of the subglacial lobes, resulting in water infiltration and the production of pseudopillow fractures. Estimates of the total meltwater produced $\left(-0.07 \mathrm{~km}^{3}\right.$; determined in the same manner as for the Mazama Ridge flow) are much lower than for the Mazama Ridge case $\left(\sim 0.35 \mathrm{~km}^{3}\right)$, and unlike the larger example, the presence of pseudopillow fractures at South Sister indicates small amounts of meltwater ponding.

\subsection{Evaluating Future Hazards}

The glaciers present on modern stratovolcanoes are much smaller than when the Cascade lava flows were emplaced in contact with ice. As a consequence, potential hazards are lower today. Today, many previously ice-covered volcanoes are now unglaciated or have glaciers of insignificant volume. Lava erupted periglacially commonly diverts around glaciers rather than intruding or flowing over them. In addition, thin glaciers ( $<100 \mathrm{~m}$ thick) are less likely to constrain large lava flows (on the scale of ridge-forming lavas) and less likely to trap large volumes of meltwater.

Hazards still exist at volcanoes, such as Mount Rainier, that still have significant glacial cover. On the basis of historic observations of lava-ice interaction, we can predict that hazards will be greatest early in an eruption when extrusion rates and heat flow are highest (especially when accompanied by lava fountaining onto ice) and when drainage channels and trenches are being eroded in the ice. After such channels are established, both the rate of meltwater production and the potential hazards are reduced. Hazards would increase again if the channel were to become blocked, allowing meltwater to accumulate or if there were a sudden increase in effusion rate.

\subsection{Hypothetical Flow Down Nisqually Glacier, Mount Rainier}

We have combined historical eruption observations and the insight gained through field studies of lava-ice interaction features to predict the behavior of a hypothetical future lava flow down the Nisqually drainage at Mount Rainier (Figure 11a). The Nisqually drainage is a likely flow path for lava erupted from Mount Rainier's most recently active summit crater and has existing maps of subglacial topography [Driedger and Kennard, 1986]. We have chosen an initial meltwater channel width of $150 \mathrm{~m}$, using the same channel width as the Mazama Ridge lava flow described above and comparable to that observed during the 1994 Llaima, Chile, eruption (from $50 \mathrm{~m}$ to $150 \mathrm{~m}$ ) [Moreno and Fuentealba, 1994].

At the onset of eruption, glacial runoff will increase dramatically due to increased heat flow, explosions, and lava flow initiation near the vent. Warm meltwater will travel down the Nisqually drainage, thermally and mechanically eroding the ice along the topographically lower western margin of the glacier (Figure $11 \mathrm{~b}$ ). At the confluence with Wilson Glacier, meltwater flow will likely enter subglacial tunnels, but melting and collapse of overlying ice should eventually result in the formation of an open trench with the Nisqually Glacier on one side and Wilson Glacier on the other (Figure $11 \mathrm{~b}$ ). Lava flowing down the Nisqually drainage would then be funneled along the eroded glacier margin.

Near where the lava flow would cross the 12,000-foot $(3658 \mathrm{~m})$ contour, the subglacial topography slopes steeply away from the glacier margin. As a result, continued erosion of the glacial margin will likely result in some undercutting of the Nisqually Glacier (Figure 1lb). Collapse of the undercut ice walls would cause channel widening and might result in sudden meltwater production or temporary ice dams. At lower elevations, glacial undercutting should be reduced due to the flatter subglacial floor of the valley.

Lava ponding and bench formation may occur at the confluence of the Nisqually and Wilson Glaciers if a meltwater channel does not exist. Once this channel is formed, the lava flow would become constrained along a currently subglacial ridge that separates the glacial drainages. Undercutting by subglacial meltwater flow down the sides of this ridge would promote local water accumulations and the formation of small lava lobes away from the main lava flow (Figure 1lb). Beyond the Wilson Glacier, the lava flow should continue along the western margin of the Nisqually Glacier, potentially to its terminus.

The primary hazards associated with such an eruption would be from flooding. By estimating the difference in ice volume before and after the hypothetical eruption (Figures $11 \mathrm{a}$ and $11 \mathrm{~b}$, respectively), we find that at least $0.03 \mathrm{~km}^{3}$ of meltwater could be produced. The greatest melt discharge rate would likely be during initial establishment of the channel. Possible sudden surges of meltwater might be caused by temporary damming of the channel during subglacial flow or by collapse of glacial walls due to undercutting.

Probably the greatest hazards during this hypothetical eruption would come from sudden increases in lava effusion rate. While such increases are hard to predict, we know they can have devastating consequences. During eruptions at Villarrica in 1971 and 1984, sudden increases in effusion rate resulted in dramatic increases in meltwater production and also collapse of the leading edge of the lava flow [GonzálezFerran, 1973; McClelland et al., 1989]. Lava flow collapses can produce block and ash flows capable of scouring the glacial surfaces and producing large debris flows. Work by Vallance [1995] and T.W. Sisson (personal communication, 1997) suggests that lava flow collapse and resultant debris flow production have occurred on numerous occasions during the Quaternary at Mount Rainier and therefore must be considered seriously during an evaluation of potential hazards.

Mount Rainier is currently at a low level of activity and the paths and effusion rates of future lava flows are uncertain. The hypothetical eruption presented above is for only one drainage. A more thorough evaluation of potential hazards at Mount Rainier, or at other volcanoes, could be made by constructing flow projections for all of the volcano's drainages assuming a variety of vent locations and eruption 

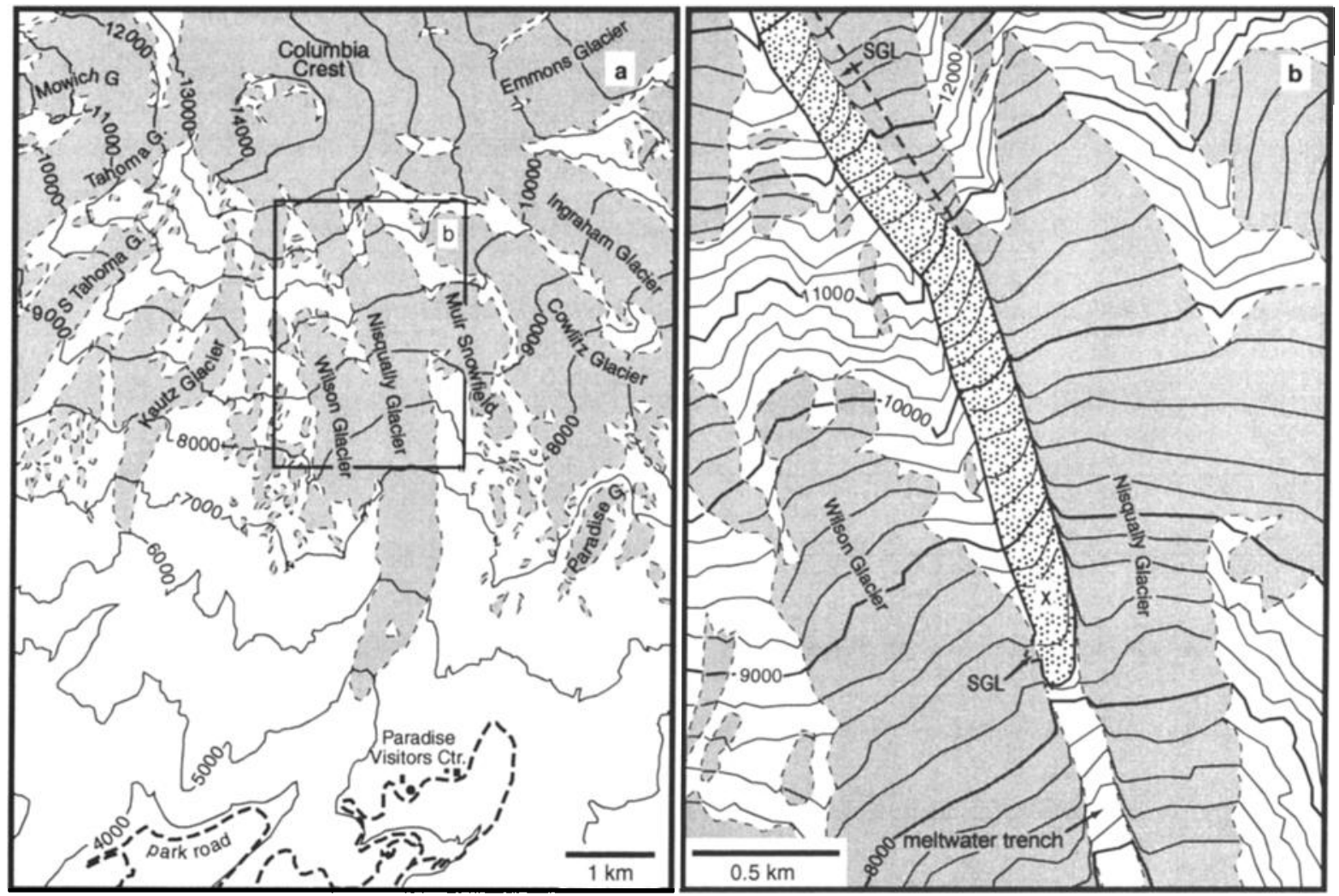

Figure 11. Predicted path that a lava flow (stippled area) would take down the Nisqually Glacier, Mount Rainier, Washington. Shaded areas correspond to glaciers; contours are in feet. (a) Current topography and glacial extent [based on Driedger and Kennard, 1986, Plate 1]. Box shows location of Figure 11b. (b) Glacial runoff down the Nisqually Glacier would likely form a trench along the west side of the glacier that would subsequently be occupied by the lava flow. Owing to the sloping subglacial topography, some undercutting of the ice is expected (indicated by dashed line and SGL, subglacial lava). At the confluence of the Nisqually and Wilson Glaciers (indicated by X), meltwater would pond and/or erode a trench (as shown) between the two glaciers. At this point the lava would be flowing on along the crest of a currently subglacial ridge and might have small offshoots to either side (SGL). The lava would continue down the trench and might reach the glacial terminus depending on the duration of the eruption.

rates. Alternatively, lava flow projections could be made following the onset of eruption and after the flow has begun traveling down a specific drainage.

\section{Conclusions}

When lava erupts in a glacial environment, two main classes of landforms result, depending on whether or not meltwater is able to escape rapidly. On stratovolcanoes where underlying slopes are steep or if ice layers are thin $(<150 \mathrm{~m}$ thick) and permeable, meltwater travels away from the vent area more freely, eroding cavities in the ice by thermal and kinetic processes [cf. Smellie et al., 1993; Smellie and Skilling, 1994]. These voids, tunnels, and trenches act as confining channels for lava that flows into them, producing unbranched flows with steep margins, which may have unusually great thickness, flat upper surfaces, and esker-like, or cylindrica,l shapes that mimic the void geometry. The landforms produced have glassy margins with polygonal fractures and include flat-topped lava mountains, steep-walled ridge flows, smaller lava flows, and one variety of dome.

Several other types of landforms are produced when the glacial voids have small volumes of ponded meltwater. These landforms have pseudopillow fractures (one type of lava dome) or isolated lava pillows (esker-like lava flows), indicative of the presence of water, and yet have the steep glassy margins indicative of flow confinement against ice. A second landform with pseudopillow fractures, pillow lobe flows, shows no evidence of flow confinement and was likely emplaced in an englacial lake.

Fractures formed during lava-ice interaction can be morphologically characterized as polygonal, sheet-like, pseudopillow, hackly, and shard-forming and correspond to increasing lava cooling rates. Pseudopillow, hackly and shard-forming fractures form during cooling by a mixture of steam and water penetrating the lava flow. Polygonal and sheet-like fractures may represent cooling by convecting steam.

Landforms produced by lava-ice interaction at stratovolcanoes can be divided into three groups: (group 1) glassy margins with polygonal fractures; (group 2) glassy margins and continuous fractures; and (group 3) glassy margins with pseudopillow fractures. These landform groups correspond to different eruption environments; group 1 landforms develop during interaction with thin glaciers.

The presence of the different fracture types can be used to locate and infer the former presence of ice and trapped meltwater at the time of eruption. By combining large- and 
small-scale field evidence with historical observations of glacial modification, it is possible to reconstruct past environmental conditions and describe various aspects of the eruption.

Insight gained by reconstructing past conditions allows us to anticipate the hazard implications of future lava flow eruptions at glaciated volcanoes. Historic observations indicate that primary concerns are the rate of ice melt and the ponding and sudden release of meltwater. By considering glacial thickness and subglacial topography we can identify where glacial undercutting and subglacial lava flow are most likely, both of which can generate increased volumes of meltwater. We can also identify where meltwater entrapment is most likely, within subglacial tunnels, beneath undercut ice cliffs, and at the confluence of glaciers. By estimating the ice available for melting and monitoring lava effusion and advance, we can make predictions regarding increased runoff and possible floods and debris flows. Sudden collapse of the lava flow front, commonly associated with increases in effusion rate, can produce mixed avalanches and large debris flows, and relevant precautions should be taken.

Acknowledgments. Work in the field benefited from the help and insight of Tom Sisson, Cathie Hickson, Charlie Bacon, Pat Muffler, Phil Long, Wes Hildreth, Cynthia Gardner, Stanley Williams, Hugo Moreno, Gustavo Fuentealba, Tina Neal, Tom Miller, Tom Pierson, and Terry Keith. We thank John Smellie, Christopher Waythomas, Jason Lore, and Penelope King whose comments greatly improved this manuscript. This work was supported by NSF grant EAR 9614330 and NASA grant NAGW 529 to J.H.F., GSA grant 5192-93 to D.T.L., and NSF grant EAR 9421455 to Stanley Williams.

\section{References}

Aydin, A., and J.M. DeGraff, Evolution of polygonal fracture patterns in lava flows, Science, 239, 471-476, 1988.

Batiza, R., and J.D.L. White, Submarine lavas and hyaloclastite, in Encyclopedia of Volcanoes, edited by H. Sigurdsson, pp. 361381, Academic, San Diego, Calif., 2000.

Belousov, A.B., Block-and-ash pyroclastic flows of basaltic composition generated by secondary phreatomagmatic explosions on lava flows: A new type of volcanic hazard demonstrated by the 1994 eruption of Kluchevskoy volcano (Kamchatka), in Pan Pacific Hazards '96 Conference and Trade Show, p. 29. Disaster Preparedness Resour. Cent., Univ. of B.C., Vancouver, 1996.

Bemmelen, R.W.v., and M.G. Rutten, Tablemountains of Northern Iceland, 217 pp., E. J. Brill USA, Kinderhook, N.Y., 1955.

Benson, C.S., and R.J. Motyka, Glacier-volcano interactions on Mt. Wrangell, Alaska, Geophys Inst Univ. Alaska Fairbanks Annu. Rep., 1977-78, 1-25, 1978.

Bonnichsen, B., and D.F. Kauffmann, Physical features of rhyolite lava flows in the Snake River Plain volcanic province, southwestern Idaho, in The Emplacement of Silicic Domes and Lava Flows, edited by J.H. Fink, Spec. Pap. Geol. Soc. Am., 212, $119-145,1987$.

Budkewitsch, P., and P.-Y. Robin, Modeling the evolution of columnar joints, J. Volcanol Geotherm Res., 59, 219-239, 1994.

Byers, F.M., D.M. Hopkins, K.L. Wier, and B. Fisher, Volcano investigations on Umnak Island, 1946, US. Geol. Surv. Alaskan Volcano Invest. Rep., 2, 19-53. 1947.

Conrey, R.M., Geology and petrology of the Mt. Jefferson area, High Cascade Range, Oregon, Ph.D. dissertation thesis, Wash. State Univ., Pullman, 1991.

Corte, A., and A. Higashi, Experimental research on desiccation cracks in soil, Cold Reg. Res. and Eng. Lab. Res. Rep. 66, 76 pp., Hanover, N.H., 1964.

DeGraff, J.M., and A. Aydin, Surface morphology of columnar joints and its significance to mechanics and direction of joint growth, Geol. Soc. Am. Bull, 99, 605-617, 1987.
DeGraff, J.M., and A. Aydin, Effect of thermal regime on growth increment and spacing of contraction joints in basaltic lava, $J$. Geophys Res., 98, 6411-6430, 1993.

DeGraff, J.M., P.E. Long, and A. Aydin, Use of joint-growth directions and rock textures to infer thermal regimes during solidification of basaltic lava flows, J. Volcanol. Geotherm. Res., 38, 309-324, 1989.

Dragoni, M., A dynamical model of lava flows cooling by radiation, Bull. Volcanol., 51, 88-95, 1989.

Driedger, C.L., and P.M. Kennard, Ice volumes on Cascade volcanoes: Mount Rainier, Mount Hood, Three Sisters, and Mount Shasta, U.S Geol. Surv. Prof. Pap., 1365, 28 pp., 1986.

Easterbrook, D.J., Mount Baker eruptions, Geology, 3, 679-682, 1975.

Fink, J.H., and R.W. Griffiths, Radial spreading of viscous-gravity currents with solidifying crust, J. Fluid Mech., 221, 485-509, 1990.

Fink, J.H., and R.W. Griffiths, Morphology, eruption rates, and rheology of lava domes: Insights from laboratory models, $J$. Geophys. Res., 103, 527-545, 1998.

Fridleifsson, I.B., H. Furnes, and F.B. Atkins, Subglacial volcanicsOn the control of magma chemistry on pillow dimensions, $J$. V'olcanol. Geotherm Res., 13, 103-118, 1982.

Furnes, H., I.B. Fridleifsson, and F.B. Atkins, Subglacial volcanicsOn the formation of acid hyaloclastites, J. Volcanol. Geotherm. Res., 8, 95-110, 1980.

González-Ferran, O., Description of volcanic eruptions-Villarrica, Bull. Volcanol. Erupt., 1I, 41-42, 1973.

Gregg, T.K.P., and J.H. Fink, Quantification of extraterrestrial lava flow effusion rates through laboratory simulation, $J$ Geophys. Res., 101, 16,891-16,900, 1996.

Griffiths, R.W., and J.H. Fink, Solidifying Bingham extrusions: A model for the growth of silicic lava domes, J. Fluid Mech., 347, 13-36, 1997.

Grossenbacher, K.A., and S.M. McDuffie, Conductive cooling of lava: columnar joint diameter and stria width as function of cooling rate and thermal gradient, J. Volcanol. Geotherm. Res., 69, 95-103, 1995.

Guffanti, M., M.A. Clynne, and L.J.P. Muffler, Thermal and mass implications of magmatic evolution in the Lassen volcanic region, California. and minimum constraints on basalt influx to the lower crust, J. Geophys Res, 101, 3003-3013, 1996.

Hammond, P.E., Lone Butte and Crazy Hills: Subglacial volcanic complexes. Cascade Range. Washington, in Cordilleran Section, Centen. Field Guide vol. I, edited by M.L. Hill, pp. 339-344, Geol Soc. of Am., Boulder, Colo., 1987.

Hardee. H.C.. Solidification in Kilauea Iki lava lake, J. Volcanol Geotherm. Res., 7, 211-223, 1980.

Hon, K., J. Kauahikaua, R. Denlinger, and K. Mackay, Emplacement and inflation of pahoehoe sheet flows: Observations and measurements of active lava flows on Kilauea volcano, Hawaii, Geol. Soc Am. Bull., 106, 351-370, 1994.

Hull, D.. and B.D. Caddock, Simulation of prismatic cracking of cooling basalt lava flows by the drying of sol-gels, J. Mater. Sci., $34,5707-5720,1999$.

Jacger, J.C., Cooling and solidification of igneous rocks, in Basalts: The Poldervaart Treatise on Rocks of Basaltic Composition, edited by H.H. Hess and A. Poldervaart, pp. 503-536, WileyInterscience, New York, 1968.

Keszthelyi, L.. and R. Denlinger, The initial cooling of pahoehoe flow lobes. Bull. Volcanol., 58, 5-18, 1996.

Khrenov, A.P., A.Y. Ozerov, N.E. Litasov, Y.B. Slezin, Y.D. Murav'ev, and N.A. Zharinov, Parasitic eruption of Klyuchevskoi volcano (Predskazannyi eruption, 1983), Volcanol. Seismol., 7, 124, 1988.

Lachenbruch, A.H., Depth and spacing of tension cracks, J. Geophys. Res., 66, 4273-4292, 1961.

Lescinsky, D.T., Lava flow morphology: The roles of external confinement and lava-ice interaction, Ph.D. dissertation thesis, 209 pp., Ariz. State Univ., Tempe, 1999.

Lescinsky, D.T., and T.W. Sisson, Ridge-forming, ice-bounded lava flows at Mount Rainier, Washington, Geology, 26, 351-354, 1998.

Long, P.E., and B.J. Wood, Structures, textures, and cooling histories 
of Columbia River basalt flows, Geol Soc. Am. Bull., 97, 114$1155,1986$.

Major, J.J., and C.G. Newhall, Snow and ice perturbation during historical volcanic eruptions and the formation of lahars and floods, Bull. Volcanol., 52, 1-27, 1989.

Manley, C.R., Extended cooling and viscous flow of large, hot rhyolite lavas: Implications of numerical modeling results, $J$. Volcanol. Geotherm. Res., 53, 27-46, 1992.

Marston, R.A., Supraglacial stream dynamics on the Juneau Icefield, Ann. Assoc. Am. Geogr., 73, 597-608, 1983.

Mathews, W.H., "Tuyas," flat-topped volcanoes in northern British Columbia, Am. J. Sci., 245, 560-570, 1947.

Mathews, W.H., The Table, a flat-topped volcano in southern British Columbia, Am. J. Sci., 249, 830-841, 1951.

Mathews, W.H., lce-dammed lavas from Clinker Mountain, southwestern British Columbia, Am. J. Sci., 250, 553-565, 1952a.

Mathews, W.H., Mount Garibaldi, a supraglacial Pleistocene volcano in southwestern British Columbia, Am. J. Sci., 250, 81-103, $1952 b$.

Mathews, W.H., Geology of the Mount Garibaldi map-area, southwestern British Columbia, Canada, Geol. Soc. Am. Bull., 69, $179-198,1958$

McClelland, L. T. Simpkin, M. Summers, E. Nielsen, and T.C. Stein (Eds.), Global Volcanism 1975-1985, 657 pp., AGU, Washington, D.C., 1989.

Meyer, D.F., and D.C. Trabant, Lahars from the 1992 eruptions of Crater Peak, Mount Spurr volcano, Alaska, in The 1992 Eruptions of Crater Peak Vent, Mount Spurr Volcano, Alaska, edited by T.E.C. Kieth, U.S. Geol. Surv. Bull., 2139, 183-198, 1995.

Moreno R., H., and G. Fuentealba C., The May 17-19 1994 Llaima volcano eruption, southern Andes (38 $\left.42^{\prime} \mathrm{S}-71^{\circ} 44^{\prime} \mathrm{W}\right)$, Rev. Geol. Chile, 2I, 167-171, 1994.

Muller, G., Experimental simulation of basalt columns, J. Volcanol. Geotherm. Res., 86, 93-96, 1998a.

Müller, G., Starch columns: Analog model for basalt columns, $J$. Geophys. Res., I03, 15239-15253, 1998 b.

Naranjo S., J.A., H. Moreno R., and N.G. Banks, La erupción del Volcán Hudson en $1991\left(46^{\circ} \mathrm{S}\right)$, Región XI, Aisén, Chile, Serv. Nac. Geol. Min Bol., 44, 50 pp., 1993.

National Research Council, Mount Rainier, Active Cascade Volcano, 114 pp., Nat. Acad. Press, Washington, D.C., 1994.

Nemat-Nasser, S., and A. Oranratnachai, Minimum spacing of thermally induced cracks in brittle solids, J. Energy Resour. Techol., 101, 34-40, 1979.

Pierson, T.C., and R.J. Janda, Volcanic mixed avalanches: A distinct eruption-triggered mass-flow process at snow-clad volcanoes, Geol. Soc. Am. Bull., 106, 1351-1358, 1994.

Pierson, T.C., R.J. Janda, J.-C. Thouret, and C.A. Borrero, Perturbation and melting of snow and ice by the 13 November 1985 eruption of Nevado del Ruiz, Colombia, and consequent mobilization, flow and deposition of lahars, J. Volcanol. Geotherm. Res., 4l, 17-66, 1990.

Reeder, J.W., and M. Doukas, Description of volcanic eruptionsWestdahl, Bull. Volcol. Erupt., 31, 83-86, 1994.

Reiter, M., M.W. Barroll, J. Minier, and G. Clarkson, Thermomechanical model for incremental fracturing in cooling lava flows, Tectonophysics, 142, 241-260, 1987.

Ryan, M.P., and C.G. Sammis, Cyclic fracture mechanisms in cooling basalt, Geol. Soc. Am. Bull., 89, 1295-1308, 1978.

Saemundsson, K., Interglacial lava flows in the lowlands of southern Iceland and the problem of two-tiered columnar jointing, Jökull, 20, 62-77, 1970.

Scott, K.M., J.W. Vallance, and P.T. Pringle, Sedimentology, behavior, and hazards of debris flows at Mount Rainier, Washington, U.S. Geol. Surv. Prof. Pap., I547, 56 pp., 1995.

Scott, W.E., Holocene rhyodacite eruptions on the flanks of South Sister volcano, Oregon, in The Emplacement of Silicic Domes and Lava Flows, edited by J.H. Fink, Spec. Pap. Geol. Soc. Am., 212, 35-53, 1987

Sisson, T.W., An overview of the geology of Mount Rainier's volcanic edifice, Eos Trans. $A G U, 76(46)$, Fall Meet. Suppl., F643, 1995.

Sisson, T.W., and M.A. Lanphere, The growth of Mount Rainier, Cascade Arc, USA, in IAVCEI Conference on Volcanic Activity and the Environment, January 1997, p. 5, Gobierno de Jalisco, Unidad Editorial, Puerto Vallarta, Mexico, 1997.

Sisson, T.W., and M.A. Lanphere, K-Ar ages of selected Mount Rainier lava flows, GSA Data Repository ltem 9840, 1998.

Smellie, J.L., Subglacial eruptions, in Encyclopedia of Volcanoes, edited by H. Sigurdsson, pp. 403-418, Academic, San Diego, Calif., 2000.

Smellie, J.L., and I.P. Skilling, Products of subglacial volcanic eruptions under different ice thicknesses: two examples from Antarctica, Sediment. Geol., 91, 115-129, 1994.

Smellie, J.L., M.J. Hole, and P.A.R. Nell, Late Miocene valleyconfined subglacial volcanism in northern Alexander Island, Antarctic Peninsula, Bull. Volcanol., 55, 273-288, 1993.

Smithsonian Institution, Descriptions of volcanic events-Westdahl, Global Volcanism Network Bull., 16 (11), 2; (12), 3, 1991.

Smithsonian Institution, Descriptions of volcanic eventsVeniaminof, Global Volcanism Network Bull., 18 (7), 3-4; (10), 3-4, 1993.

Smithsonian Institution, Descriptions of volcanic eventsKliuchevskoi, Global Volcanism Network Bull., 19 (8), 11-12; (9), 2, 1994a.

Smithsonian Institution, Descriptions of volcanic eventsVeniaminof, Global Volcanism Network Bull., 19 (2), 6-7; (4), 8$9 ;(9), 14,1994 \mathrm{~b}$.

Taylor, E.M., N.S. MacLeod, D.R. Sherrod, and G.W. Walker, Geologic map of the Three Sisters Wilderness, Deschutes, Lane, and Linn Counties, Oregon. Scale 1:63,360, U.S. Geol. Surv. Misc. Field Ser. Map, MF-1952, 1987.

Trabant, D.C., R.B. Waitt, and J.J. Major, Disruption of Drift Glacier and origin of floods during the 1989-1990 eruptions of Redoubt Volcano, Alaska, J. Volcanol. Geotherm. Res., 62 (1-4), 369-385, 1994

U.S. Geological Survey, Mount Rainier East, Washington, U.S. Geol. Surv 7.5 Min. Topo. Quad., 1971.

U.S. Geological Survey, South Sister, Oregon, U.S. Geol. Surv 7.5 Min. Topo. Quad., 1988.

Vallance, J.W., Holocene tephras and history of Mount Rainier volcano, Eos Trans AGU, 76 (46), F644, Fall Meet. Suppl., 1995.

Vinogradov, V.N., and Y.D. Murav'ev, Lava-ice interaction during the 1983 Klyuchevskoi eruption, Volcanol. Seismol., 7, 39-61, 1988.

Vinogradov, V.N., Y.D. Murav'ev, I.M. Nikitina, and A.N. Salmatin, Production of phreatic explosions in the interaction of lava and ice, Volcanol. Seismol., 9, 89-98, 1990.

Waitt, R.B., Swift snowmelt and floods (lahars) caused by great pyroclastic surge at Mount St. Helens volcano, Washington, 18 May 1980, Bull. Volcanol., 52, 138-157, 1989.

Walder, J.S., Nature of depositional contacts between pyroclastic deposits and snow or ice, in Hydrologic Consequences of HotRock/Snowpack Interactions at Mount St. Helens Volcano, Washington, edited by T.C. Pierson, U.S. Geol. Surv. Prof. Pap., 1586, 9-18, 1999.

Walker, G.P.L., Morphometric study of pillow-size spectrum among pillow lavas, Bull. Volcanol., 54, 459-474, 1992.

Walker, G.P.L., Basaltic-volcano systems, in Magmatic Processes and Plate Tectonics, edited by H.M. Prichard et al., Geol. Soc. Spec. Publ., 76, 3-38, 1993.

Walker, G.P.L., and D.H. Blake, The formation of a palagonite breccia mass beneath a valley glacier in Iceland, Quat. $J$. Geol. Soc. London, 122, 45-61, 1966.

Watanabe, K, and Y. Katsui, Pseudo-pillow lavas in the Aso caldera, Kyushu, Japan, J. Minera. Petrol. Econ. Geol., 71, 44-49, 1976.

Wilding, M., D. Dingwell, R. Batiza, and L. Wilson, Cooling rates of hyaloclastites: applications of relaxation geospeedometry to undersea volcanic deposits, Bull. Volcanol., 6l, 527-526, 2000.

Wilding, M.C., S.L. Webb, and D.B. Dingwell, Cooling rate variation in natural volcanic glasses from Tenerife, Canary Islands, Contrib. Mineral. Petrol., 125, 151-160, 1996.

Wright, A.C., Landforms of McMurdo Volcanic Group, southern foothills of the Royal Society Range, Antarctica, N. Z. J. Geol. Geophys., 23, 605-613, 1980.

Yamagishi, H., Morphological and sedimentological characteristics of the Neogene submarine coherent lavas and hyaloclasites in southwest Hokkaido, Japan, Sediment. Geol., 74, 5-23, 1991 a. 
Yamagishi, H., Morphological features of Miocene submarine coherent lavas from the "Green Tuff" basins: examples from basaltic and andesitic rocks from the Shimokita Peninsula, northern Japan, Bull. Volcanol., 53, 173-181, 199lb.

Yount, M.E., T.P. Miller, R.P. Emanuel, and F.H. Wilson, Eruption in the ice-filled caldera of Mount Veniaminof, U.S. Geol. Surv. Circ., 945, 58-60, 1985.

Zharinov, N.A., S.A. Khubunaya, Y.V. Demyanchyk, V.N. Dvigalo, and V.Y. Kirianov, Description of volcanic eruptionsKliucheskoi, Bull. Volcanol. Erupt., 33, 79-84, 1996.
J.H. Fink, Department of Geology, Box 871404, Arizona State University, Tempe, AZ 85287-1404. (jon.fink@asu.edu)

D.T. Lescinsky, Department of Earth Sciences, University of Western Ontario, London, ON N6A 5B7, Canada. (dlescins@julian.uwo.ca)

(Received December 7, 1999; revised May 17, 2000;

accepted June 7, 2000) 